NBER WORKING PAPER SERIES

\title{
EXAMINING THE EFFECT OF THE EARNED INCOME TAX CREDIT ON THE LABOR MARKET PARTICIPATION OF FAMILIES ON WELFARE
}

\author{
V. Joseph Hotz \\ Charles H. Mullin \\ John Karl Scholz \\ Working Paper 11968 \\ http://www.nber.org/papers/w11968 \\ NATIONAL BUREAU OF ECONOMIC RESEARCH \\ 1050 Massachusetts Avenue \\ Cambridge, MA 02138 \\ January 2006
}

We thank Glen Cain, Liz Davis, Janet Holtzblatt, Tom MaCurdy, Bruce Meyer, and numerous seminar participants for comments, and Dawn Duren, Eduardo Fajnzylber, Webb Hester, Doug Houston, Jacob Klerman, Doug McKee, Oscar Mitnik, Don Oellerich, Juan Pantano, George Ramsey, Pat Ruggles, and Werner Schink for their help with this project. We also thank colleageues at the California Department of Social Services; the California Franchise Tax Board; RAND; the National Science Foundation; and the Department of Health and Human Services, Office of the Assistant Secretary for Planning and Evaluation, who collectively helped support this work. The views expressed herein are those of the author(s) and do not necessarily reflect the views of the National Bureau of Economic Research.

(C2006 by V. Joseph Hotz, Charles H. Mullin and John Karl Scholz. All rights reserved. Short sections of text, not to exceed two paragraphs, may be quoted without explicit permission provided that full credit, including (C) notice, is given to the source. 
Examining the Effect of the Earned Income Tax Credit on the Labor Market Participation of Families on Welfare

V. Joseph Hotz, Charles H. Mullin and John Karl Scholz

NBER Working Paper No. 11968

January 2006

JEL No. H2, J2

\section{$\underline{\text { ABSTRACT }}$}

This paper examines the employment effects of the earned income tax credit (EITC). We use a unique dataset, created by matching administrative data from public assistance records, unemployment insurance records, and federal tax returns for a sample of California residents. We conduct a set of four tests to assess our ability to isolate the causal effects of the EITC on employment. The first test is based on the intuition that if the EITC alters employment, all else being equal, employment rates for two-or-more child families should grow relative to the employment rates of one-child families, as credit amounts available to these groups of families diverged over the 1990s. The second test examines whether or not people eligible for the EITC actually file tax returns and claim it. The third test is based on the intuition that, if the EITC, and not other factors such as the strong economy in the 1990s, is causing employment differences between families with two or more children relative to those with one child, we should expect to see no employment differences (after conditioning on other characteristics) between families with two children and families with three or more children, since the EITC did not change differentially for the latter two groups. The fourth test conditions the sample on those who do not file tax returns and again examines employment changes in the 1990s for families with two or more children relative to families with one child.

Using fixed-effects empirical employment models estimated on a sample of single-parent families, our coefficient estimates are consistent with the EITC having a substantial, positive effect on the employment of families who have used or will use welfare.

V. Joseph Hotz

Department of Economics

Box 951477

UCLA

Los Angeles, CA 90095-1477

and NBER

$\underline{\text { hotz@ucla.edu }}$
John Karl Scholz

University of Wisconsin - Madison

Department of Economics

1180 Observatory Drive

Madison, WI 53706

and NBER

jkscholz@wisc.edu 


\section{Examining the Effect of the Earned Income Tax Credit on the Labor Market Participation of Families on Welfare}

Between 1990 and 1999, real spending on the earned income tax credit (EITC) increased to \$31.9 billion from $\$ 9.6$ billion (in 1999 dollars). It is by far the largest cash or near-cash antipoverty policy in the United States. Moreover, with phased-in increases enacted in 1990 and in 1993, it became the most rapidly growing (substantial) item in the federal budget.

Employment rates of single women with children also rose sharply over this period, and welfare caseloads fell precipitously. Between March 1990 and March 2000, employment rates of single women with children rose to 73.9 percent from 55.2 percent. Welfare caseloads fell to 2.3 million families from 4.1 million (though caseloads rose until 1994, when they peaked at 5.0 million families). ${ }^{1}$

The coincident timing of these trends raises a question: did the EITC play a substantial role in the increase in labor force participation of single women with children? ${ }^{2}$ Not surprisingly, given the important role the EITC plays in the nation's safety net, a number of previous studies examine this topic. ${ }^{3}$ These papers come to a consistent conclusion: the EITC has a significant, empirically large effect on labor force participation of single women with children. ${ }^{4}$

${ }^{1}$ Employment rates and caseload numbers come from Tables No. 577 and No. 544, respectively, from Statistical Abstract of the United States 2000.

${ }^{2}$ Standard labor-leisure models unambiguously predict that EITC increases (or increases in other wage subsidies) will increase employment among low-skilled workers.

${ }^{3}$ For published work, see Dickert, Houser, and Scholz (1995); Eissa and Leibman (1996); Keane and Moffitt (1998); Ellwood (2000); Meyer and Rosenbaum (2000, 2001); Grogger (2003); and Eissa and Hoynes (2004). Hotz and Scholz (2003) survey EITC research.

${ }^{4}$ Hotz and Scholz (2003) compute employment elasticities with respect to net income (associated with EITC changes) from selected previous studies that range from 0.69 to 1.16. Grogger's (2003) estimates were not included in our earlier study, but he concludes that the EITC "may be the single most important policy measure for explaining the decrease in welfare and the rise in work and earnings among female-headed families in recent years" (p. 408). Eissa and Hoynes (2004) focus on the employment and hours decisions of secondary workers in married families and find small, negative effects of the credit on work. Cancian and Levinson (2003) use data from the National Survey of America's Families and focus on Wisconsin's supplemental EITC for families with three or more children. Unlike other studies on the topic, they do not find statistically significant EITC employment effects. 
At least three concerns arise with previous work examining the EITC’s employment effects. The identification strategy in most papers is to compare employment changes of groups eligible for the EITC (generally single mothers) with employment changes of groups ineligible for the EITC (generally single women without children) before and after EITC increases. ${ }^{5}$ But other factors changed over the periods in which the EITC increased, and these other factors might have different employment effects for women with and without children. Many states, for example, made extensive changes to welfare both before and after the Personal Responsibility and Work Opportunity Reconciliation Act (PRWORA) abolished AFDC in 1996. And aggregate GDP increased 120 consecutive months beginning in March 1991, resulting in the longest economic expansion in U.S. history.

A second issue arises with the difference-in-difference approach: namely, that the composition of the groups may change over time. There are a priori reasons to be concerned about potential compositional bias in these repeated cross-sectional studies. ${ }^{6}$ Between 1984 and 1996, for example, the period examined in Meyer and Rosenbaum (2001), the number of single mothers in the Current Population Survey (CPS) increased 30.5 percent, to 7.7 million families from 5.9 million families. ${ }^{7}$ The difference-in-difference identification strategy will be biased in indeterminate directions if employment propensities of the sample changed over time after accounting for observed characteristics (Heckman, 1996).

${ }^{5}$ Keane and Moffitt (1998) estimate utility function parameters of households that are consistent with participation decisions in multiple welfare programs, accounting for the precise budget sets that occur in the 1984 SIPP. Dickert, Houser, and Scholz (1995) do not observe EITC variation in their cross-sectional study and consequently they infer the potential effects of the EITC from observing the correlation between employment and differences in the return to work across states. These employment differences, however, may be due to unobserved state-specific factors unrelated to differences in the return to work generated by the tax and transfer systems.

${ }^{6}$ All previous studies use repeated cross-sectional data from the Current Population Survey (CPS) and the Survey of Income and Program Participation (SIPP) except for Cancian and Levinson (2003).

${ }^{7}$ As discussed in Hotz and Scholz (2002), the ratio of AFDC recipients reported in the CPS to administrative counts of recipients fell from 86.7 percent in 1990 to 79.6 percent in 1996. The ratio of AFDC dollars to administrative totals was 78.4 percent in the 1984 CPS and 67.7 percent by 1996 . By all accounts the SIPP and CPS are of high quality, but these trends raise a concern about the ability of studies using the CPS or SIPP to accurately characterize the tax and transfer environment facing low-income families. 
Third, all previous EITC employment studies have been indirect in the sense that they have inferred the EITC's effects based on the relationship between employment and EITC policy changes. But if EITC changes cause employment changes, we should see similar changes in EITC claims. Because of data limitations, no previous study has directly examined EITC claiming and employment.

This paper addresses these and other concerns. We use data only from California to mitigate the influence of changes in welfare and other social policies on employment and to better account for local labor market conditions. ${ }^{8}$ Using data with county identifiers, we are able to include considerably more detailed covariates to proxy for local labor market conditions than have previous studies. ${ }^{9}$ Moreover, California also made relatively modest changes to AFDC and TANF compared to other states in the 1990s. We nevertheless also condition on several features of the county-administered welfare programs in California.

Ours is also the first EITC employment study to use longitudinal data, which allow us to account for unobserved, household-specific, time-invariant factors that affect employment. Longitudinal data also help us avoid bias due to (unobserved) changes in the composition of "treatment” and "comparison" groups in repeated cross-sectional studies.

At the core of our empirical analysis is a set of four tests that we use to assess the causal effects of the EITC on employment. The first test examines employment using a different identification strategy than most previous studies that typically compare employment rates of women with children to other groups. Beginning in 1991, the maximum EITC available to families with two or more children increased relative to the EITC available for one-child families. While the difference in the maximum credit by number of children was initially modest, starting in 1994, as a result of changes in the EITC included in

\footnotetext{
${ }^{8}$ See Ellwood (2000) for more on these issues.
}

${ }^{9}$ Bartik and Eberts (1999) criticize studies that include only unemployment rates to account for labor market conditions, writing, the "... unemployment rate by itself may be a woefully incomplete measure of economic conditions affecting potential welfare recipients.” They argue that more textured measures of the economic environment facing welfare families matter in understanding caseload changes. 
the 1993 federal budget act, this differential increased substantially, the maximum credit rising from \$77 in 1993 to \$490 in 1993 to \$1,404 in 1996 (see Table 1). If the EITC alters employment, all else being equal, employment rates for families with two or more children should grow relative to the employment rates of families with one child, as credit amounts available to these groups of families diverge. ${ }^{10}$ Our empirical approach formalizes this strategy as a “difference-in-difference” estimator, controlling for covariates and household-specific fixed effects, to identify the effects of the EITC on employment.

The second test makes use of a unique match of administrative data on welfare receipt, unemployment records, and the federal tax returns filed by California residents, which allow us to examine directly the employment and EITC-claiming behavior of low-income families. No previous EITC employment study has used data on whether or not people eligible for the EITC actually file tax returns and claim it. If the employment patterns previous studies attribute to the EITC are, in fact, caused by the credit, those who are affected by the credit should file and claim it.

If the EITC, and not other factors such as the strong economy in the 1990s, is causing employment differences between families with two or more children relative to those with one child, we should expect to see no employment differences (after conditioning on other characteristics) between families with two children and families with three or more children, since the EITC did not change differentially for the latter two groups. Our third test examines this proposition.

Our fourth test conditions the sample on those who do not file tax returns, and again examines employment changes in the 1990s for families with two or more children relative to families with one child. If the EITC is the factor causing employment changes in the data, we would expect to see no

\footnotetext{
${ }^{10}$ In a sensitivity analysis section, Meyer and Rosenbaum (2001) examine differences in labor market effects generated by the EITC for families with two or more children relative to families with one child, as is done in our paper. They find much smaller EITC effects in this alternative specification and the coefficients are insignificant in their larger, CPS Outgoing Rotation Group sample. Cancian and Levinson (2003) use a similar approach and find insignificant EITC employment effects.
} 
differential employment changes for the two groups (again, after conditioning on other characteristics) among those not filing tax returns (and hence not claiming the credit).

Using fixed-effects empirical employment models estimated on a sample of single-parent families, our coefficient estimates are consistent with the EITC having a substantial, positive effect on the employment of families who have or will use welfare. Patterns of EITC claiming mirror the employment patterns. Moreover, the differential employment responses occur only for families with two or more children relative to one child, and not for families with three or more children relative to families with exactly two children. Finally, there is no differential expansion of employment for families with two or more children relative to one-child families for those who do not file tax returns. If factors other than the EITC were driving the employment patterns observed in the data, it is unlikely that they would only affect those who file tax returns and not affect the employment of families with three or more children relative to families with two children.

We also discuss sensitivity analyses that show our results are robust to alternative modeling choices. The most striking aspect of the sensitivity analysis, however, is that the EITC has no discernible effect on employment for AFDC-UP (two-parent) families.

The remainder of the paper is organized as follows. In Section 1 we describe the structure and history of the EITC, the various data sources we use and how we construct our analysis sample of households who were on welfare in California for some period of time during 1990s. In Section 2 we present unadjusted difference-in-difference estimates of the annual effects of the EITC on employment rates and rates of EITC claiming for the period 1992-2000. In Section 3 we present refined estimates for both of these outcomes using multivariate regression methods. In Section 4 we present the results for the four tests described above as well as the results of several additional sensitivity analyses we conducted. We conclude the paper with a summary of our findings and a discussion of how they compare with those found in previous studies. 


\section{THE EITC AND CALIFORNIA ADMINISTRATIVE DATA}

In 1999, taxpayers with two or more children could receive an EITC of 40 percent of income up to $\$ 9,540$, for a maximum credit of $\$ 3,816$. Taxpayers (with two or more children) with earnings between $\$ 9,540$ and $\$ 12,460$ receive the maximum credit. Their credit is reduced by 21.06 percent of earnings between $\$ 12,460$ and $\$ 30,585$. Table 1 shows the complete evolution of income eligibility thresholds, credit rates, and phase-out (or implicit tax) rates.

To receive the credit, taxpayers file their regular tax return and fill out the six-line Schedule EIC that gathers information about qualifying children. The EITC is refundable, meaning that the Treasury Department pays it out regardless of whether the taxpayer has any federal income tax liability. There are several basic tests for EITC eligibility. The taxpayer's earned income and adjusted gross income must be below a threshold that varies by year and by family size. To receive the credit available to families with children, ${ }^{11}$ the qualifying child must be younger than 19 , younger than 24 if a full-time student, or any age if totally disabled. The claimant must be the parent, the grandparent, or foster parent of the child. ${ }^{12}$ The qualifying child must live with the taxpayer at least six months during the year.

A key development for the purposes of this paper was put in place as part of the 1990 EITC expansions. After 1990, for the first time, families with two or more children were able to receive a larger EITC than they could if they had only one child. The difference through 1993, however, never exceeded \$77. As part of the 1993 EITC expansion, the differences became much larger: the maximum difference was \$490 in 1994, \$1,016 in 1995, and \$1,404 in 1996 (and indexed for inflation thereafter). As noted in the introduction, if the EITC alters employment, all else being equal, employment rates for two-or-more-

${ }^{11} \mathrm{~A}$ small credit available for childless taxpayers between the ages 24 in 65 with very low incomes was added in 1994. The credit rate for these taxpayers is 7.65 percent and the maximum credit in 1999 is \$347.

${ }^{12}$ Until late 1999, a foster child was any child for whom the claimant cared for "as if the child is his or her own.” Now the caring stipulation still holds, but the child must also be placed in the home by an authorized placement agency. 
Table 1

Earned Income Tax Credit Parameters, 1987-2000 (in nominal dollars)

\begin{tabular}{|c|c|c|c|c|c|c|}
\hline Year & $\begin{array}{l}\text { Phase-In } \\
\text { Rate (\%) }\end{array}$ & $\begin{array}{l}\text { Phase-In } \\
\text { Range (\$) }\end{array}$ & $\begin{array}{c}\text { Max. } \\
\text { Credit (\$) }\end{array}$ & $\begin{array}{l}\text { Diff. in Max } \\
\text { Credit: } \\
2+-1 \text { Child } \\
(\$)\end{array}$ & $\begin{array}{c}\text { Phase-Out } \\
\text { Rate (\%) }\end{array}$ & $\begin{array}{l}\text { Phase-Out } \\
\text { Range (\$) }\end{array}$ \\
\hline 1987 & 14.0 & $0-6,080$ & 851 & & 10.0 & 6,920-15,432 \\
\hline 1988 & 14.0 & $0-6,240$ & 874 & & 10.0 & 9,840-18,576 \\
\hline 1989 & 14.0 & $0-6,500$ & 910 & & 10.0 & $10,240-19,340$ \\
\hline 1990 & 14.0 & $0-6,810$ & 953 & & 10.0 & $10,730-20,264$ \\
\hline $1991^{\mathrm{a}}$ & $\begin{array}{l}16.7^{1} \\
17.3^{2}\end{array}$ & $0-7,140$ & $\begin{array}{l}1,192 \\
1,235\end{array}$ & 43 & $\begin{array}{l}11.93 \\
12.36\end{array}$ & $\begin{array}{l}11,250-21,250 \\
11,250-21,250\end{array}$ \\
\hline $1992^{\mathrm{a}}$ & $\begin{array}{l}17.6^{1} \\
18.4^{2}\end{array}$ & $0-7,520$ & $\begin{array}{l}1,324 \\
1,384\end{array}$ & 60 & $\begin{array}{l}12.57 \\
13.14\end{array}$ & $\begin{array}{l}11,840-22,370 \\
11,840-22,370\end{array}$ \\
\hline $1993^{\mathrm{a}}$ & $\begin{array}{l}18.5^{1} \\
19.5^{2}\end{array}$ & $0-7,750$ & $\begin{array}{l}1,434 \\
1,511\end{array}$ & 77 & $\begin{array}{l}13.21 \\
13.93\end{array}$ & $\begin{array}{l}12,200-23,050 \\
12,200-23,050\end{array}$ \\
\hline 1994 & $\begin{array}{c}23.6^{1} \\
30.0^{2} \\
7.65^{3}\end{array}$ & $\begin{array}{l}0-7,750 \\
0-8,245 \\
0-4,000\end{array}$ & $\begin{array}{r}2,038 \\
2,528 \\
306\end{array}$ & 490 & $\begin{array}{r}15.98 \\
17.68 \\
7.65\end{array}$ & $\begin{array}{c}11,000-23,755 \\
11,000-25,296 \\
5,000-9,000\end{array}$ \\
\hline 1995 & $\begin{array}{c}34.0^{1} \\
36.0^{2} \\
7.65^{3}\end{array}$ & $\begin{array}{l}0-6,160 \\
0-8,640 \\
0-4,100\end{array}$ & $\begin{array}{r}2,094 \\
3,110 \\
314\end{array}$ & 1,016 & $\begin{array}{r}15.98 \\
20.22 \\
7.65\end{array}$ & $\begin{array}{c}11,290-24,396 \\
11,290-26,673 \\
5,130-9,230\end{array}$ \\
\hline 1996 & $\begin{array}{c}34.0^{1} \\
40.0^{2} \\
7.65^{3}\end{array}$ & $\begin{array}{l}0-6,330 \\
0-8,890 \\
0-4,220\end{array}$ & $\begin{array}{r}2,152 \\
3,556 \\
323\end{array}$ & 1,404 & $\begin{array}{r}15.98 \\
21.06 \\
7.65\end{array}$ & $\begin{array}{c}11,610-25,078 \\
11,610-28,495 \\
5,280-9,500\end{array}$ \\
\hline 1997 & $\begin{array}{c}34.0^{1} \\
40.0^{2} \\
7.65^{3}\end{array}$ & $\begin{array}{l}0-6,500 \\
0-9,140 \\
0-4,340\end{array}$ & $\begin{array}{r}2,210 \\
3,656 \\
332\end{array}$ & 1,446 & $\begin{array}{r}15.98 \\
21.06 \\
7.65\end{array}$ & $\begin{array}{c}11,930-25,750 \\
11,930-29,290 \\
5,430-9,770\end{array}$ \\
\hline 1998 & $\begin{array}{c}34.0^{1} \\
40.0^{2} \\
7.65^{3}\end{array}$ & $\begin{array}{l}0-6,680 \\
0-9,390 \\
0-4,460\end{array}$ & $\begin{array}{r}2,271 \\
3,756 \\
341\end{array}$ & 1,485 & $\begin{array}{r}15.98 \\
21.06 \\
7.65\end{array}$ & $\begin{array}{c}12,260-26,473 \\
12,260-30,095 \\
5,570-10,030\end{array}$ \\
\hline 1999 & $\begin{array}{c}34.0^{1} \\
40.0^{2} \\
7.65^{3}\end{array}$ & $\begin{array}{l}0-6,800 \\
0-9,540 \\
0-4,530\end{array}$ & $\begin{array}{r}2,312 \\
3,816 \\
347\end{array}$ & 1,504 & $\begin{array}{r}15.98 \\
21.06 \\
7.65\end{array}$ & $\begin{array}{c}12,460-26,928 \\
12,460-30,580 \\
5,670-10,200\end{array}$ \\
\hline 2000 & $\begin{array}{c}34.0^{1} \\
40.0^{2} \\
7.65^{3}\end{array}$ & $\begin{array}{l}0-6,920 \\
0-9,720 \\
0-4,610\end{array}$ & $\begin{array}{r}2,353 \\
3,888 \\
353\end{array}$ & 1,535 & $\begin{array}{r}15.98 \\
21.06 \\
7.65\end{array}$ & $\begin{array}{c}12,690-27,413 \\
12,690-31,152 \\
5,770-10,380\end{array}$ \\
\hline
\end{tabular}

Source: 1998 Green Book, Committee on Ways and Means, U.S. House of Representatives, U.S.

Government Printing Office, page 867; 1998 through 2000 parameters come from Publication 596, Internal Revenue Service.

${ }^{a}$ Basic credit only. Does not include supplemental young child or health insurance credits.

${ }^{1}$ Taxpayers with one qualifying child.

${ }^{2}$ Taxpayers with more than one qualifying child.

${ }^{3}$ Childless taxpayers. 
child families should grow relative to the employment rates of one-child families starting in 1994, as credit amounts available to these groups of families diverge.

For those out of the labor market, the EITC provides an unambiguous, positive incentive to work. We focus on this feature of the credit in this paper. ${ }^{13}$

\subsection{The Core Administrative Data Sources}

California’s Medi-Cal Eligibility Data System (MEDS) provides information on program participation and demographic characteristics of participants in Medi-Cal, the California state Medicaid program, and AFDC/CalWORKS, the California state welfare program. ${ }^{14}$ MEDS also provides AFDC participation histories of individuals in our samples starting in 1986.

We measure labor force participation using quarterly data from 1991 through 2000 on employment (and earnings) from the California Employment Development Department (EDD) Base Wage Files. The EDD Base Wage File contains employer-reported taxable wage payments for jobs covered by unemployment insurance (UI) and disability insurance (DI). ${ }^{15}$ Hotz and Scholz (2002) survey studies that examine the accuracy and coverage of unemployment insurance data for the low-income population. In brief, UI data exclude some groups of workers, such as the self-employed, military, federal employees, and independent contractors. Nevertheless, employment rates derived from UI data appear to be similar to those that result from survey data. We expect UI-based employment rates to be lower because of coverage problems with flexible workers and independent contractors. But surveys suffer from nonresponse, so undercounts in both data sources typically appear to be similar in practice.

${ }^{13}$ See Hotz and Scholz (2003) for a summary of papers examining the effects of the EITC on hours of work.

${ }^{14}$ More generally, the MEDS is a statewide administrative system that contains information on monthly participation in the state's Medicaid program (Medi-Cal), AFDC/TANF programs, as well as the Food Stamp, SSI, and California's General Assistance (GA) programs. MEDS data are used by the Department of Health and Human Services for quality control analyses and are thought to be high quality for the welfare and Medicaid populations.

${ }^{15}$ The file generally includes individuals paid cash wages of more than $\$ 100$ in a calendar quarter, and domestic workers paid cash wages more than $\$ 750$ in a calendar quarter. 
To examine tax filing and EITC claiming, we use data from federal tax returns filed by households in the MEDs data for the years 1991 through $2000 .{ }^{16}$

\subsection{Sampling}

Our core data come from a sample of all assistance units ever on welfare in California between 1987 and 2000, drawn by scholars at RAND from the statewide MEDS data. The number of California welfare recipients is very large, so the sample was drawn to maintain approximately equal numbers of observations in each county (with every observation included in smaller counties). Sampling is based on the county in which recipients are first observed receiving cash assistance, and time-invariant sampling weights are applied to each person. Approximately 50 percent of all adults ever on welfare over this period are included in the baseline RAND sample. ${ }^{17}$ We start with the RAND sample because it was linked to employment data beginning in 1991 from the California unemployment insurance system. ${ }^{18}$

Sampling refinements are invariably needed when working with administrative data. We drop roughly 6 percent of households in which no adult is a member of the AFDC assistance unit, since we do not have earnings and demographic information on the potential EITC claimant. ${ }^{19}$ We drop 8.4 percent of households that have three or more adults in AFDC-UP (two-parent) cases or have two or more adults in AFDC-FG (one-parent) cases at the time of sampling because we are unable to construct useful decision rules about which adult can claim a child for purposes of the EITC. We also exclude a small number of

\footnotetext{
${ }^{16}$ All tax data are processed at the California Franchise Tax Board, where strict procedures are followed (such as presenting data only in grouped format and removing all identifying information) to ensure compliance with tax privacy laws.

${ }^{17}$ The original RAND sample was intended to be a 17 percent sample of adults and children on welfare. But once a person was drawn into the RAND sample, all people in all of the sampled person's cases were included. The resulting sample reflects roughly (depending on the year) 50 percent of all adults ever on welfare.

${ }^{18}$ Statewide unemployment insurance data from early in the analysis period was destroyed sometime in the 1990s, making the RAND sample an essential starting point for the analysis.

${ }^{19}$ We define a child as being 18 years old or younger throughout the year. This age limit corresponds to the age of a qualifying child for EITC purposes. These child-only cases occur when the children are eligible for AFDC but the adults who live with the children are ineligible.
} 
cases in which we were unable to determine the date at which they entered the sample, in which adults were missing a birth date, in which the gender or race/ethnicity of the adults were missing, and in which no children were present in the case. Overall, we are left with 626,700 usable cases, or 82.5 percent of the original RAND sample.

We construct two data sets from this set of usable cases. To mimic the data used in previous EITC studies, we construct a set of annual cross-sectional samples for the years 1991-2000. We also construct a panel of annual data for the cases in the RAND sample.

In principle, we could construct a panel of annual data for 1991 through 2000 for each case in the RAND sample, since, as noted above, we have annual employment data from UI Base Wage records and annual data on tax filing and EITC claiming from federal tax returns. Unfortunately, the MEDS data are our only source for annual information on the number and ages of children when households do not file tax returns, and households are only in MEDS when they receive welfare. Our identification strategy is predicated on examining employment differences between families with one and with two or more children under the age of 18.

Given that we do not have comprehensive information on the number of children in the household (and their ages) for all of the years in our data, we use the following strategy to construct our longitudinal data set. For each case in the (usable) RAND sample, we draw at random a "base year" from the years that the case was on welfare during the period 1991-2000. Using this base year, we construct a case's panel using the $J$ years immediately preceding the base year, the base year, and the $K$ years immediately following the base year. Note that depending on the base year that is drawn and the values for $J$ and $K$, we can end up with "unbalanced" panels, given that we do not have data for years prior to 1991 or after 2000.

The choice of the lengths of these "lags" and "leads" (for $J$ and $K$ ) balances three considerations. First, the longer the time span before and after the base year, the greater the chance we will make errors in assessing the number of children in the family. We know the ages of children as of the base year so we 
can precisely determine their date of birth. We do not observe births occurring after the base year, at least not for cases that do not continue on welfare. Therefore, information on the number (and ages) of children in the household will likely be more accurate using data prior to the base year than using data after the base year. Second, all else being equal, having longer panels means we have more data, which will increase the precision of our estimates. Third, with fixed-effect models of employment or EITC claiming, households that change status from one child to two or more children or vice versa identify the coefficients of interest. This status changes for two reasons in our sample: children are born, or their age exceeds the EITC qualifying child age limit. Given the birth dates of children born as of the base year, we can determine births in years prior to the base year. We observe aging out as we examine employment in years following the base year.

In extensive analyses of our data using different lengths of lags (values for $J$ ) and leads (values for $K$ ), we found that households with children that are too old to be used as EITC qualifying children have substantially different observable characteristics than the typical (or mean) household on welfare in California. ${ }^{20}$ In particular, they are older, have more children, have different racial and ethnic composition, and have different earnings. Given these differences in observable characteristics, we think it is likely that there also are substantial unobserved differences. In contrast, families with children born in the four years prior to the base year are indistinguishable (besides having a young child) from all families on welfare.

To balance the above considerations and given the findings from our analyses of the properties of panels with varying lag and lead lengths, we utilize four-year panels that include the three years prior to the base year $(J=3)$ and the base year and no years after the base year $(K=0)$. Again, we note that the panels for a given case can be shorter than four years if the base year drawn (at random) for a case was 1991, 1992, or 1993.

\footnotetext{
${ }^{20}$ These analyses are available from the authors on request.
} 
For the (repeated) cross-sectional data set used in the analyses below, we used the data for the year following the randomly drawn base year (again, between 1991 and 2000) for each case in the RAND sample. This approach ensures that we have the required information on the ages and number of children for the years in which we examine households’ employment and EITC claiming behavior. Furthermore, our approach avoids the use of data that over samples long-term welfare recipients, which might distort our analyses of employment and EITC claiming behavior.

For most of the analysis, we focus on AFDC-FG (single-parent) cases, which account for 84.1 percent of the total cases (or 527,125). Single parents are by far the largest share of the welfare population and have considerably lower employment rates than two-parent families, and hence are more likely to be affected by the EITC. We conduct sensitivity analyses using the AFDC-UP (two-parent) cases.

Appendix Tables 1a and 1b show the weighted characteristics of the primary cross-sectional (Table 1a) and longitudinal analysis samples (Table 1b). Overall, average employment rates were around 48 percent. In detail not shown in the table, employment rates in the annual cross-sectional samples increase from 36.3 percent in 1991 to 65.4 percent in 2000. Recall that every household in these crosssectional samples was on welfare in the year prior to when we record employment. Thus, the economy, the EITC, welfare reform, or other factors appear to have greatly increased employment of welfare recipients over the period examined. The racial and ethnic characteristics of the population changed over time as well — the proportion of cases headed by a Hispanic increased 14 percentage points and the proportion of cases headed by a black increased 3 percentage points, while the proportion of white families fell by roughly 16 percentage points. Other features of the caseload remained roughly constant over time. More than half the cases in the sample have two or more children, while roughly 30 percent have exactly two children. 


\section{EMPLOYMENT RATES AND EITC CLAIMING BY FAMILY SIZE AND YEAR IN THE CROSS-SECTIONAL ANALYSIS SAMPLE}

In this section, we present unadjusted (for covariates) difference-in-difference estimates of household (adult) employment and EITC claiming. Let $Y_{\text {ict }}$ denote an outcome variable for the adults in the $i^{\text {th }}$ household from county $c$ in (calendar) year $t$. In our case, there are two outcome variables, whether one or more adults in a household are employed in the labor market $\left(E m p_{i c t}\right)$ and whether a household files a tax return and claims the EITC (ClaimEITC $\left.C_{i t c}\right)$, where these two outcomes are defined as follows:

$$
E m p_{\text {ict }}=\left\{\begin{array}{l}
1, \text { if at least } 1 \text { adult in } i^{\text {th }} \text { household in county } c \text { is employed in year } t \\
0, \text { otherwise }
\end{array}\right.
$$

ClaimEITC $_{i c t}=\left\{\begin{array}{l}1, \text { if } i^{\text {th }} \text { household in county } c \text { files tax return and claims EITC in year } t \\ 0, \text { otherwise }\end{array}\right.$

As noted earlier, we use the differential change in the EITC by family size before and after 1994 to identify the EITC’s employment effect and effect on EITC claiming. In particular, we use the following “difference-in-difference” estimator:

$$
\beta_{s}^{*} \equiv\left(\bar{Y}_{t^{\prime \prime}}^{2+}-\bar{Y}_{t^{\prime \prime}}^{1}\right)-\left(\bar{Y}_{t^{\prime}}^{2+}-\bar{Y}_{t^{\prime}}^{1}\right),
$$

for $t^{\prime \prime} \geq 1994>t^{\prime}$, where $\bar{Y}_{s}^{1}$ is the mean outcome in year $s$ for households that had only one child, and $\bar{Y}_{s}^{2+}$ is the corresponding mean for households that had two or more children. ${ }^{21}$ Absent cohort, welfare entry, or other sample compositional effects — a major qualification that we address in the following

\footnotetext{
${ }^{21}$ Each year we include a household in the sample if an adult (defined as being 18 or older) and at least one child (defined as being under 18) are present. Based on birth dates, we compute ages of household members each analysis year and reclassify a household appropriately. For example, consider a woman with two children, born in 1992 and 1994. Prior to 1992, we drop this household since no children existed. We classify the household as having a single child from 1992 to 1994 and as having two children after that. If the panel were longer, in 2011 the eldest child would be too old and the household would revert to a one-child classification.
} 
sections - we expect, if the EITC stimulates employment and/or rates of EITC claiming, to see higher rates of these outcomes for two-plus child families relative to one-child families as the EITC differential between the two types of families begins to increase substantially in $1994 .^{22}$

We first present estimates for employment rates in Table 2a. The "Diff-in-Diff” column of Table 2a suggests that the EITC expansion beginning in 1994 may have had a significant, positive effect on the employment rates, though if the EITC is the causal mechanism, either its influence is occurring with a considerable lag or other factors not accounted for in the table mask the EITC’s effect. In particular, employment rates for both one-child families and for families with two or more children are steady in the 1991-93 base period and then begin to rise sharply in 1994. However, the employment increases for families with one child and for families with two or more children are equivalent until 1997, the year after the EITC changes are fully phased in. The differences in employment rates for families with two or more children and one-child families are large and highly statistically significant beginning in 1998. Of course, these patterns may be the result of other factors changing over this period, including the economy, the welfare system, and compositional issues related to entry and exit of our sample.

A unique feature of our analysis is having access to the individual tax returns household file. Table 2b shows a similar set of difference-in-difference calculations where the outcome is filing a tax return and claiming the EITC. The temporal pattern of EITC claiming is similar to the pattern for employment. Households with two or more children are between 2 and 2.5 percentage points less likely to claim the EITC from 1991 through 1995. This differential starts narrowing in 1996 and by 2000 families with two or more children are 4.2 percentage points more likely to claim the EITC. As with the employment estimates, many things could account for the patterns of EITC filing that we observe.

We refine our analysis of employment and claiming the EITC in the next section.

1996.

\footnotetext{
${ }^{22}$ Recall that the full $\$ 1,404$ maximum differential in the EITC by number of children does not occur until
} 


\section{MULTIVARIATE ANALYSIS OF EMPLOYMENT AND EITC CLAIMING}

The unadjusted difference-in-difference estimates presented in Tables 2a and 2b may not isolate the effects of the EITC on employment or EITC claiming for at least three related reasons. The first is that the number of children a household has may have a separate influence on these outcomes over and above the influence of the EITC. Second, and related to the first, economic models of household time allocation and fertility decisions imply that the number of children (and their age composition) and employment outcomes are jointly determined by observable and possibly unobservable factors that determine household's tastes, home and market productivity, etc. ${ }^{23}$ Third, there are potentially other policy changes, most importantly changes in welfare policy, that occurred around the time of the EITC expansion in the 1990s that may have affected the employment decisions of households with differing numbers of children. In an attempt to account for factors that may compromise the validity of the unadjusted EITC effect estimates in Tables 2a and 2b, we also present several alternative sets of "adjusted" difference-indifference estimates using regression methods.

The first set of adjustments is based on the following regression function:

$$
\begin{aligned}
Y_{i c t}= & \phi+\sum_{s=1992}^{2000} \alpha_{S} \text { Year_s } s_{t}+\sum_{s=1994}^{2000} \beta_{s}\left[2+K i d s_{i c t} \cdot Y e a r \_s_{t}\right]+\sum_{j=1}^{9} \delta_{j} \text { Kids_} j_{i c t}+\sum_{k=1}^{17} \psi_{k} \text { KidsAge_k } k_{i t c} \\
& +\kappa X_{i c}+\lambda W_{c t}+\eta L_{c t}+\sum_{m=1}^{55} \theta_{m} \text { County_m } m_{c}+\varepsilon_{i c t}
\end{aligned}
$$

where Year_s is an indicator variable equal to 1 if the current year $t$ equals $s$ and 0 otherwise, $s=$ $1992, \ldots, 2000 ; 2+K i d s_{i c t}$ is an indicator variable equal to 1 if the household has two or more children in year $t$; Kids $j_{i c t}$ is an indicator variable equal to 1 if there $j$ children in the household in year $t$ and 0 otherwise, $j=1, \ldots, 9$ where the category ' 9 ' is for 9 or more children; KidsAge_ $k_{\text {ict }}$ equals the number of children in the household that are age $k$ in year $t, k=1, \ldots, 17 ; X_{i c}$ denotes a vector of time-invariant

\footnotetext{
${ }^{23}$ See, for example, Hotz and Miller (1988).
} 
Table 2a

Employment Rates (in Percentages) by Family Size, 1991-2000, Repeated Cross-Sectional Samples

\begin{tabular}{|c|c|c|c|c|c|}
\hline Year & All Cases & $\begin{array}{l}\text { Cases with } \\
\text { One Child }\end{array}$ & $\begin{array}{c}\text { Cases with } \\
2+\text { Children }\end{array}$ & $\begin{array}{l}\text { Difference } \\
\text { (2+ - One) }\end{array}$ & $\begin{array}{c}\text { Diff-in-Diff } \\
\text { (199x - 1991-93 } \\
\text { Average) } \\
\end{array}$ \\
\hline 1991 & $\begin{array}{c}36.35 \\
{[65,567]}\end{array}$ & $\begin{array}{c}39.43 \\
{[27,568]}\end{array}$ & $\begin{array}{c}33.82 \\
{[37,999]}\end{array}$ & -5.61 & \\
\hline 1992 & $\begin{array}{c}34.82 \\
{[56,787]}\end{array}$ & $\begin{array}{c}38.35 \\
{[24,433]}\end{array}$ & $\begin{array}{c}31.76 \\
{[32,354]}\end{array}$ & -6.59 & \\
\hline 1993 & $\begin{array}{c}35.40 \\
{[52,630]}\end{array}$ & $\begin{array}{c}38.89 \\
{[23,098]}\end{array}$ & $\begin{array}{c}32.3 \\
{[29,532]}\end{array}$ & -6.59 & \\
\hline 1994 & $\begin{array}{c}40.20 \\
{[54,407]}\end{array}$ & $\begin{array}{c}43.65 \\
{[24,005]}\end{array}$ & $\begin{array}{c}37.12 \\
{[30,402]}\end{array}$ & -6.53 & $\begin{array}{l}-0.31 \\
(0.66)\end{array}$ \\
\hline 1995 & $\begin{array}{c}44.89 \\
{[56,664]}\end{array}$ & $\begin{array}{c}48.44 \\
{[25,500]}\end{array}$ & $\begin{array}{c}41.64 \\
{[31,164]}\end{array}$ & -6.8 & $\begin{array}{l}-0.58 \\
(0.66)\end{array}$ \\
\hline 1996 & $\begin{array}{c}48.51 \\
{[55,713]}\end{array}$ & $\begin{array}{c}51.03 \\
{[25,457]}\end{array}$ & $\begin{array}{c}45.87 \\
{[30,256]}\end{array}$ & -5.16 & $\begin{array}{c}0.79 \\
(0.67)\end{array}$ \\
\hline 1997 & $\begin{array}{c}55.20 \\
{[53,444]}\end{array}$ & $\begin{array}{c}57.73 \\
{[24,794]}\end{array}$ & $\begin{array}{c}52.78 \\
{[28,650]}\end{array}$ & -4.95 & $\begin{array}{l}1.27^{*} \\
(0.68)\end{array}$ \\
\hline 1998 & $\begin{array}{c}61.34 \\
{[48,653]}\end{array}$ & $\begin{array}{c}62.32 \\
{[22,479]}\end{array}$ & $\begin{array}{c}60.4 \\
{[26,174]}\end{array}$ & -1.92 & $\begin{array}{l}4.31^{* * * *} \\
(0.69)\end{array}$ \\
\hline 1999 & $\begin{array}{c}63.60 \\
{[41,039]}\end{array}$ & $\begin{array}{c}65.01 \\
{[19,066]}\end{array}$ & $\begin{array}{c}62.22 \\
{[21,973]}\end{array}$ & -2.79 & $\begin{array}{l}3.43^{* * *} \\
(0.74)\end{array}$ \\
\hline 2000 & $\begin{array}{c}65.41 \\
{[42,221]} \\
\end{array}$ & $\begin{array}{c}66.03 \\
{[19,731]} \\
\end{array}$ & $\begin{array}{r}64.84 \\
{[22,490]} \\
\end{array}$ & -1.19 & $\begin{array}{l}5.03^{* * *} \\
(0.74) \\
\end{array}$ \\
\hline
\end{tabular}

Note: The entries in the table give mean rates, (standard deviations), and [number of households (cases)]. ${ }^{*},{ }^{* *}$, and ${ }^{* * *}$ denote statistical significance at the 10,5 , and 1 percent levels, respectively. 
Table 2b

EITC Claiming (in Percentages) by Family Size, 1991-2000, Repeated Cross-Sectional Samples

\begin{tabular}{|c|c|c|c|c|c|}
\hline Year & All Cases & $\begin{array}{l}\text { Cases with } \\
\text { One Child } \\
\end{array}$ & $\begin{array}{c}\text { Cases with } \\
2+\text { Children } \\
\end{array}$ & $\begin{array}{l}\text { Difference } \\
\text { (2+ - One) }\end{array}$ & $\begin{array}{c}\text { Diff-in-Diff } \\
\text { (199x - 1991-93 } \\
\text { Average) } \\
\end{array}$ \\
\hline 1991 & $\begin{array}{c}24.13 \\
{[65,567]}\end{array}$ & $\begin{array}{c}25.48 \\
{[27,568]}\end{array}$ & $\begin{array}{c}23.02 \\
{[37,999]}\end{array}$ & -2.46 & \\
\hline 1992 & $\begin{array}{c}22.76 \\
{[56,787]}\end{array}$ & $\begin{array}{c}23.80 \\
{[24,433]}\end{array}$ & $\begin{array}{c}21.85 \\
{[32,354]}\end{array}$ & -1.95 & \\
\hline 1993 & $\begin{array}{c}22.88 \\
{[52,630]}\end{array}$ & $\begin{array}{c}23.90 \\
{[23,098]}\end{array}$ & $\begin{array}{c}21.97 \\
{[29,532]}\end{array}$ & -1.93 & \\
\hline 1994 & $\begin{array}{c}27.84 \\
{[54,407]}\end{array}$ & $\begin{array}{c}28.87 \\
{[24,005]}\end{array}$ & $\begin{array}{c}26.91 \\
{[30,402]}\end{array}$ & -1.96 & $\begin{array}{c}0.17 \\
(0.59)\end{array}$ \\
\hline 1995 & $\begin{array}{c}32.95 \\
{[56,664]}\end{array}$ & $\begin{array}{c}34.11 \\
{[25,500]}\end{array}$ & $\begin{array}{c}31.89 \\
{[31,164]}\end{array}$ & -2.22 & $\begin{array}{l}-0.09 \\
(0.61)\end{array}$ \\
\hline 1996 & $\begin{array}{c}35.60 \\
{[55,713]}\end{array}$ & $\begin{array}{c}35.83 \\
{[25,457]}\end{array}$ & $\begin{array}{c}35.34 \\
{[30,256]}\end{array}$ & -0.49 & $\begin{array}{l}1.69 * * * \\
(0.63)\end{array}$ \\
\hline 1997 & $\begin{array}{c}42.34 \\
{[53,444]}\end{array}$ & $\begin{array}{c}42.80 \\
{[24,794]}\end{array}$ & $\begin{array}{c}41.91 \\
{[28,650]}\end{array}$ & -0.89 & $\begin{array}{l}1.24^{*} \\
(0.66)\end{array}$ \\
\hline 1998 & $\begin{array}{c}47.46 \\
{[48,653]}\end{array}$ & $\begin{array}{c}46.72 \\
{[22,479]}\end{array}$ & $\begin{array}{c}48.18 \\
{[26,174]}\end{array}$ & 1.46 & $\begin{array}{l}3.60 * * * \\
(0.69)\end{array}$ \\
\hline 1999 & $\begin{array}{c}51.28 \\
{[41,039]}\end{array}$ & $\begin{array}{c}50.18 \\
{[19,066]}\end{array}$ & $\begin{array}{c}52.35 \\
{[21,973]}\end{array}$ & 2.17 & $\begin{array}{l}4.31^{* * *} \\
(0.75)\end{array}$ \\
\hline 2000 & $\begin{array}{c}51.94 \\
{[42,221]}\end{array}$ & $\begin{array}{c}49.80 \\
{[19,731]}\end{array}$ & $\begin{array}{c}53.99 \\
{[22,490]}\end{array}$ & 4.19 & $\begin{array}{l}6.32 * * * \\
(0.75)\end{array}$ \\
\hline
\end{tabular}

Note: The entries in the table give mean rates, (standard deviations), and [number of cases].

$*$, **, and ${ }^{* * *}$ denote statistical significance at the 10,5 , and 1 percent levels, respectively. 
demographic characteristics of the $i^{\text {th }}$ household; $W_{c t}$ denotes a vector of county-level measures of California's welfare caseload and policies affecting this caseload; $L_{c t}$ denotes a vector of time-varying indicators of county-level labor market conditions; County_ $m_{i c t}$ is an indicator variable equal to 1 if the $i^{\text {th }}$ household resides in county $m, m=1, \ldots, 55$; and $\varepsilon_{i t c}$ is an independently and identically distributed error term.

The parameters, $\beta_{s}$, in (4) denote year-specific differential effects of having two or more children on the outcome and, thus, are the adjusted (for covariates) version of the unadjusted difference-indifference estimator, $\left(\beta_{s}^{*}\right)$, defined in (3) and for which estimates are presented in Tables 2a and 2b. Estimates of these and the other parameters in (4) can be obtained by estimating (4) by ordinary least squares (OLS), using the repeated cross-sectional data described in Section 1.2.

Using the longitudinal data, we also estimate a generalization of the regression specification in (4), modifying it to allow for household-specific fixed effects as follows:

$$
\begin{aligned}
Y_{i c t}= & \phi_{i}+\sum_{s=1992}^{2000} \tilde{\alpha}_{s} Y e a r \_s_{t}+\sum_{s=1994}^{2000} \tilde{\beta}_{s}\left[2+K i d s_{i c t} \cdot \text { Year_s } s_{t}\right]+\sum_{j=1}^{9} \tilde{\delta}_{j} \text { Kid__ } j_{i c t}+\sum_{k=1}^{17} \tilde{\psi}_{k} \text { KidsAge } k_{i t c} \\
& +\tilde{\lambda} W_{c t}+\tilde{\eta} L_{c t}+\sum_{m=1}^{55} \tilde{\theta}_{m} \text { County_m } m_{c}+\varepsilon_{i c t}^{*} .
\end{aligned}
$$

The time-invariant households variables $\left(X_{i c}\right)$ are not included in (5) as these factors will be absorbed by the $\phi_{i}$ s. In essence, controlling for the $\phi_{i}$ s allows us to account for all time-invariant characteristics of the household, such as educational attainment, work readiness, motivation, etc., that might affect household employment decisions and the likelihood of filing a tax return and claiming the EITC. 
We note that both of the outcomes we analyze, Emp and ClaimEITC, are dichotomous dependent variables so that the specifications in (4) and (5) characterize linear probability models. ${ }^{24}$ In both of these specifications, while we assume that $\varepsilon_{i c t}$ is independent across households, we do adjust the standard errors on the regression coefficients for correlations within a household across time.

Two crucial assumptions are needed for our empirical model to be sensible. First, any independent effects on employment of being in the "treatment” or "control” groups do not vary temporally. Put differently, one-child and multi-child families (the building blocks of the treatment and control groups) respond identically to changes in economic conditions and welfare policies over the period being analyzed after conditioning on other characteristics. ${ }^{25}$ We include an extensive set of covariates to increase the likelihood that this condition holds, and examine the robustness of our results in longitudinal and cross-sectional samples. Our four-part test of employment effects also addresses this concern. Second, we assume that the distribution of employment propensities (conditional on covariates) for the populations of one-child and multi-child families remain stable before and after the EITC expansion. Our longitudinal analysis mitigates, if not eliminates, this potential problem, at least relative to papers in the existing literature. ${ }^{26}$

We now briefly describe the actual variables that compose the vectors $X_{i c}, W_{c t}$, and $L_{c t}$ included in regression specifications (4) and (5).

\footnotetext{
${ }^{24}$ We present fixed effect linear probability results in our longitudinal analyses since they are particularly easy to interpret and they are computationally less demanding given our large samples than panel logits or alternative approaches.

${ }^{25}$ See Heckman and Robb (1985) and Moffitt and Wilhelm (2000) for further details on difference-indifference estimators.

${ }^{26}$ With repeated cross-sectional data, maintaining the second assumption is more problematic. It requires the distribution of employment propensities (conditional on covariates) for the populations of childless, one-child, and multi-child single women to remain stable over the period being analyzed. To the extent that different groups of households enter the sample before and after the intervention and these groups differ, even if only with respect to their time-invariant employment propensities, the assumption is unlikely to hold with repeated cross-sectional data.
} 


\subsection{Other Influences of Children and Household Characteristics}

Employment rates tend to increase as people and children age. We include a detailed set of covariates to account for the composition and characteristics of the family. We include 18 variables counting the number of children at each age, from 0 to 17, in the household in the particular analysis year. We also include a set of dummy variables corresponding to the number of children in the household in each year. In empirical specifications that exclude household fixed effects, we also include indicator variables for female, Hispanic, black, Asian, or mixed or other races or ethnicities (leaving whites as the excluded category). We also include a variable for the mean age of adults in the household.

\subsection{Influences of California’s Welfare Programs}

Beginning in October 1992, California altered its AFDC program, under a series of waivers granted by the U.S. Department of Health and Human Services. ${ }^{27}$ Judged by the standards of welfare experimentation and reform elsewhere, the changes were fairly modest. The most important change was to reduce the maximum amount of AFDC cash aid by 15 percent. ${ }^{28}$ Static models of labor supply, under usual assumptions about income and substitution effects, predict that the combination of the reduction in the guaranteed levels of AFDC benefits and other features of the package will tend to increase employment. Evaluations of California's welfare changes, however, suggest the effects of the changes (collectively known as “California Work Pays”) were modest (Becerra et al., 1998; Hotz, Mullin, and

\footnotetext{
${ }^{27}$ Hotz, Mullin, and Scholz (2002a, 2002b) evaluate the effects of these changes on employment, income, and welfare use.

${ }^{28}$ The other changes were also designed to encourage employment. These changes (a) eliminated the 100 hour (per month) work limitation once a household started receiving AFDC-UP; (b) eliminated the time limit for the $\$ 30$ and 1/3 income disregard; (c) encouraged pregnant teens and teen parents to stay in or return to school by providing child care, transportation, and other assistance, and created disincentives for bad grades or for dropping out of school; (d) raised (modestly) asset limits for families once they start receiving benefits; (e) allowed AFDC-eligible persons to decline an AFDC cash grant, but still receive Medi-Cal (the Medicaid program in California) and child care assistance; and (f) made California's Job Opportunities and Basic Skills (JOBS) training program and the Greater Avenues for Independence (GAIN) program more work-oriented.
} 
Scholz, 2002a, 2002b). ${ }^{29}$ Consequently, welfare changes seem an unlikely candidate for explaining substantial changes in employment among California’s welfare population.

Nevertheless, we include in the empirical model a measure summarizing county-level enrollments as a percentage of each county’s AFDC caseload in California’s welfare-to-work program, Greater Avenues for Independence (GAIN). Counties could implement different GAIN programs and were free to change them over this period. ${ }^{30}$

In the analysis of the repeated cross-sectional data, we also include a set of indicator variables for each entry cohort onto welfare. These control for differences in labor force participation associated with the passage of time after initial AFDC receipt. They also help account for differences in entry cohorts across years that may be related to economic conditions. These indicator variables drop out of the longitudinal analyses, since the household-specific fixed effect accounts for time-invariant characteristics of households.

Low-income households in California (and elsewhere) are potentially eligible for other social assistance programs that may affect their decisions to work. These other programs, such as Medi-Cal, Food Stamps, and SSI, did not change much or at all over this period. They also generally did not vary across California’s 58 counties. Thus, we do not attempt to control for the effects of other programs on labor force participation, beyond including year dummies in the analysis. ${ }^{31}$

\footnotetext{
${ }^{29}$ Meyers, Glazer, and MacDonald (1998) examine implementation of California Work Pays based on 66 intake or recertification interviews in 1993 and 1994. Their evidence suggests little was done to convey the broad message of work pays to clients. They write, "Only one office had a Work Pays poster within sight of clients. Two workers were observed to have Work Pays buttons. When asked about the button, however, one of the two reported that she had obtained it from her union—as part of a campaign to make 'work pay' for county employees” (p. 12).

${ }^{30}$ For more on the GAIN program and the differences in its implementation in California's counties, see Riccio, et al. (1989) and Hotz, Imbens, and Klerman (2005).

${ }^{31}$ In the empirical models using cross sectional data we also include a full set of county dummies. The results are also unaffected by including a full set of county-by-year interaction variables, which account for countyspecific trends.
} 
In the sensitivity analysis, we add a variable showing county-level spending by year in stateprovided child care assistance. Public child care expenditures were small in California in the early 1990s, but increased sharply late in the decade (Marrufo, O’Brien-Strain, and Oliver, 2003). These expenditures could influence employment patterns, so we control for them to help ensure that our results are not driven primarily by changes in child care spending.

\subsection{Influences of Local Labor Market Conditions}

Some of the changes in welfare caseloads and employment rates of low-skilled workers during the 1990s may be attributable to changes in labor market conditions. To account for the role of the economy, we examine several labor market characteristics, including the overall employment rate in the 58 California counties; the share of employment in manufacturing, service, and retail trade (the employment share in government services is the excluded category); income per worker in each county, and income per worker in each sector in the county (again, excluding government services).

There is substantial cross-county variation in local economic conditions across California. We summarize these trends and differences by graphing the annual employment to population ratios across California regions in Figure $1 .^{32}$ Employment-to-population ratios are less than 55 percent in the northern and mountain counties of California (they are less than 35 percent in Calaveras County), whereas they exceed 75 percent by the late 1990s in the Bay Area. Statewide, average county-level employment-topopulation ratios fell from 62 percent to 61 percent during the recession early in the decade and increased to 68 percent by 2000 .

Figure 2 presents similar statistics, showing annual real earnings (in \$1,000s of 1992/93 dollars) per service sector worker across California regions. Average annual earnings in the mountain and

\footnotetext{
${ }^{32}$ Similar figures for disaggregated sectors are available on request. These data were obtained from the website of the Labor Market Information Division (LMID) of the State of California's Economic Development Department.
} 
northern counties ranged from $\$ 20,700$ to $\$ 25,000$, but range from $\$ 37,100$ to $\$ 52,300$ in the Bay Area. Statewide average annual earnings range between $\$ 33,200$ and $\$ 38,900$. These figures document the unusually large variation in economic conditions across California counties.

As mentioned above, we also include indicator variables for years in our empirical model to account for aggregate business-cycle effects. Descriptive statistics are given in Appendix Tables 1a and $1 \mathrm{~b}$ for the variables that we use in the $X, L$, and $W$ vectors when estimating regression models (4) and (5).

\section{IDENTIFYING THE EFFECTS OF THE EITC}

Our first test examines employment differences between families with two or more children relative to one-child families, using two different empirical models: a fixed-effects model with additional time-varying household and county-level covariates and a (repeated) cross-sectional model with timevarying and invariant covariates. If the EITC increases employment, we expect to see employment for families with two or more children rise relative to the employment of one-child families after 1993.

If the EITC causes differential employment increases, families should file tax returns and claim the EITC. Our second test examines this intuition by estimating fixed-effects and repeated cross-sectional empirical models of households claiming the EITC.

Our identification strategy implies that if the EITC affects employment and we have accounted suitably for other factors affecting employment, employment rates should increase for families with two or more children relative to one-child families. But employment rates of families with three or more children should not differ from those with exactly two children because the EITC expansions treat these groups identically. To construct our third test, we define a new dummy variable that identifies households with exactly two children and include that, interacted with year dummies, in the longitudinal empirical model (5). The two-child dummy variable is defined as:

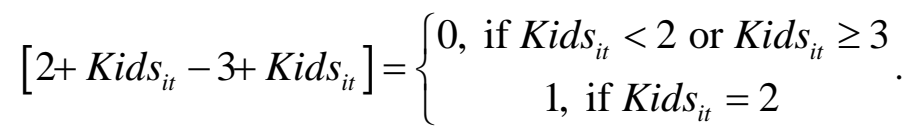


Figure 1: Annual Employment to Population Ratios, California, 1992-2000

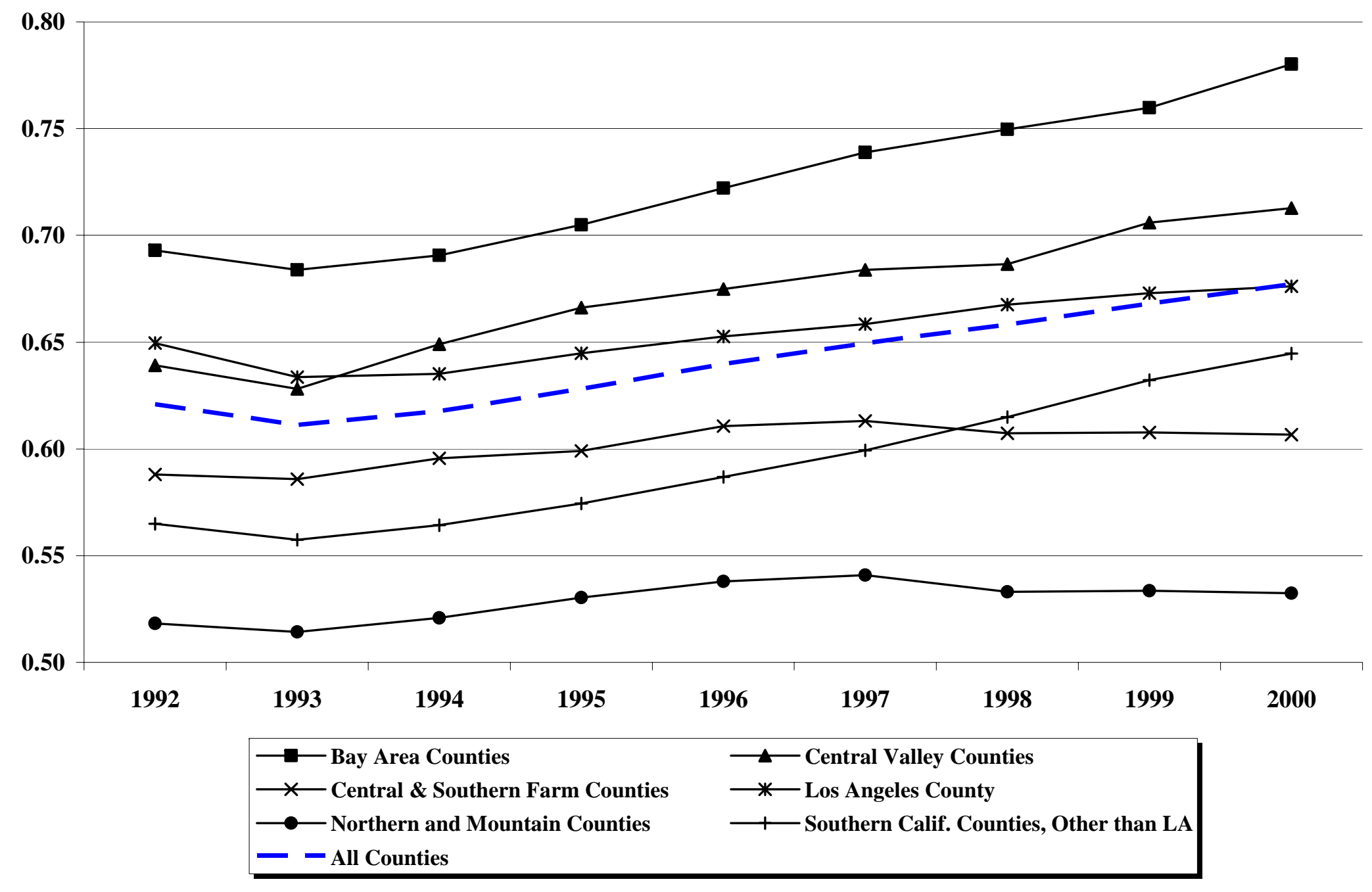


Figure 2: Annual Real Earnings per Worker in Service Sector, California, 1992-2000

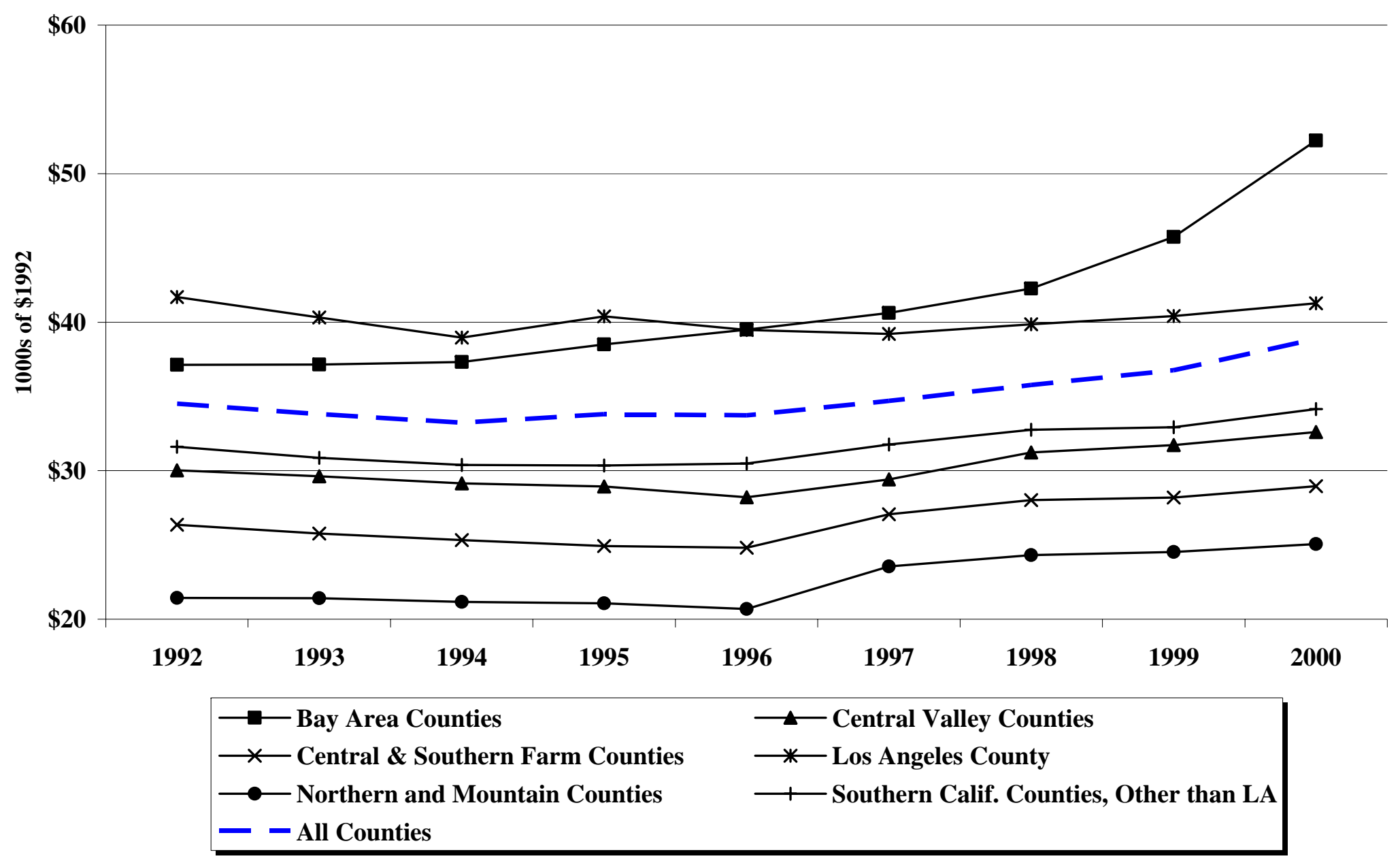


Our hypothesis is that the coefficients on this dummy variable interacted with year dummies should be insignificant individually and jointly for the years following the differential EITC expansion by family size. ${ }^{33}$ The idea is that if factors unrelated to the EITC are causing the differential employment changes by family size, they would also result in differences between families with two children and three or more children (and 22 percent of the sample has three or more children). In this way, the specification check helps us distinguish EITC changes, which only affect relative employment of families with one and two or more children, from other potential explanations.

If the EITC causes differential employment increases, we would expect them to be present only for families who file tax returns. Our fourth test examines this intuition by conditioning the sample of households who do not file returns: we do not expect to see employment increase over time for families with two or more children relative to one-child families in this alternative sample. ${ }^{34}$

\subsection{Tests 1 and 2: Multivariate Model Estimates of Employment and EITC Claiming}

Table 3 presents results for our repeated cross-section and fixed-effects regression specifications. (All specifications have a similar structure, though specifications without household fixed effects include additional covariates, as noted above. Complete results are available on request.) The dependent variable indicates whether or not the adult in the household participated in the labor market (i.e., had positive EDD earnings) during the year. In the repeated cross-sectional models (estimated with OLS methods),

\footnotetext{
${ }^{33}$ The difference-in-difference estimate for families with two children relative to one-child families is the sum of the coefficients on the " $\left[2+\right.$ Kids $_{i t} \times$ Year $\left.s_{t}\right]$ " and " $\left[2+\right.$ Kids $_{i t}-3+$ Kids $\left._{i t}\right] \times$ Year $\_s_{t}$ " terms. The difference-in-difference estimate for families with three or more children relative to one-child families is the coefficients on the " $\left[2+\right.$ Kids $_{i t} \times$ Year $\left.\_s_{t}\right]$ " terms. It follows that the test of whether there is a difference between the effects for families with two children relative to the effects for families with three or more children is whether the " $\left[2+\right.$ Kids $_{i t}-3+$ Kids $\left._{i t}\right] \times$ Year_s $s_{t}$ " term is zero for each year and whether they are jointly equal to zero across years.

${ }^{34}$ The fourth test, of course, conditions the sample on an endogenous variable, tax filing. We nevertheless think the test is informative in the sense that if some spurious factor (and not the EITC) were generating the empirical patterns found in the first three tests, we would expect the spurious factor to also affect the employment of households not filing tax returns.
} 
employment is measured in the year following the date of sampling (which occurs in the fourth quarter of the previous year). Each OLS regression includes an extensive set of covariates, shown in Appendix Table 1a. The disadvantage of the repeated cross-sectional specification is that it does not include the household-specific effects. The advantage is that there are likely to be fewer errors in measuring the number and ages of children in the household and other household characteristics. We prefer the fixedeffects estimates, but finding results consistent with the longitudinal analysis with the repeated crosssectional data would strengthen our interpretation.

The results for the first test mirror the unconditional employment estimates given in Table 2a. Reading on the right-hand side of the table (the fixed-effects estimates), the estimates on the variables " $2+$ Kids in $Y r$ ” for $Y r=1994, \ldots, 2000$, show that employment rates for those with two or more children are statistically indistinguishable from the employment rates of one-child families in 1994 and 1995, conditioning on the fixed effects and other covariates. Employment rates for families with two or more children are 1.2 percentage points higher in 1996, 2.6 percentage points higher in 1997, 3.2 percentage points higher in 1998, 3.4 percentage points higher in 1999, and 3.0 percentage points higher in 2000, relative to employment rates for one-child families.

The repeated cross-sectional results in Table 3 are similar to the previous results, though they provide somewhat weaker evidence of positive EITC employment effects. Employment for families with two or more children increases significantly in 1998 through 2000 relative to employment of families with one child.

Results for the second test are given in Table 4, which shows repeated cross-sectional OLS and panel data, fixed-effects specification estimates of EITC claiming. The estimates from both models mirror the employment results from Table 3. EITC claiming by families with two or more children is insignificantly different from EITC claiming by one-child families in 1994 and 1995. Between 1996 and 2000 families with two or more children are significantly more likely to claim the EITC than are families with one child (the fixed-effects estimates are only marginally significant in 2000 and the repeated cross- 
sectional estimates are insignificant in 1997). If the EITC is responsible for the employment differentials between families with two or more children compared to one-child families, the Table 4 estimates reflect the pattern of EITC claiming we would expect to see.

The empirical models in Tables 3 and 4 include a number of additional correlates of employment and EITC claiming (complete results are available on request). There are very strong year effects, with employment increasing by 24 percentage points from its low point in 1993 to its high point in 2000. EITC claiming increases by 35 percentage points between 1992 and 2000. As shown in Table 1, the EITC increased substantially over the 1990s, both in levels (for all families with children) as well as increasing disproportionately for larger families (which is the focus of this paper). Along with the broad EITC expansion, groups around the country engaged in considerable outreach. ${ }^{35}$ The fact that EITC claiming increased more rapidly than employment suggests that the combination of larger potential EITC payments along with outreach efforts induced more households, especially those with positive earnings, to claim the credit.

The family size variables have opposite effects on employment and EITC claiming. Employment increases steadily with the age of the children. Relative to the excluded category of 18-year-old children, households with a child under 2 are 9 to 16 percentage points less likely to work. GAIN enrollments appear to increase employment and EITC claiming, but the economic magnitude of the estimated correlation is small. Conditioning on other covariates, counties with 100 percent of their caseload enrolled in GAIN have employment rates (EITC claiming rates) 1.6 (2.3) percentage points higher than counties where nobody enrolled in GAIN.

\footnotetext{
${ }^{35}$ The Center for Budget and Policy Priorities, for example, has had a long-standing national EITC outreach campaign. For a recent example, see http://www.cbpp.org/eic2005/. There are many other examples from every part of the country.
} 
Table 3

Estimates of EITC Effects on Household Employment

\begin{tabular}{|c|c|c|}
\hline Variable & $\begin{array}{c}\text { OLS, Repeated } \\
\text { Cross-Sectional Samples }\end{array}$ & $\begin{array}{c}\text { Household Fixed } \\
\text { Effects, Panel Data }\end{array}$ \\
\hline \multirow[t]{2}{*}{ 2+ Kids in 1994} & 0.0001 & -0.0035 \\
\hline & $(0.0065)$ & $(0.0041)$ \\
\hline \multirow[t]{2}{*}{ 2+ Kids in 1995} & -0.0063 & 0.0072 \\
\hline & $(0.0065)$ & $(0.0052)$ \\
\hline \multirow[t]{2}{*}{ 2+ Kids in 1996} & 0.0040 & $0.0123^{* *}$ \\
\hline & $(0.0066)$ & $(0.0061)$ \\
\hline \multirow[t]{2}{*}{ 2+ Kids in 1997} & 0.0092 & $0.0261 * * *$ \\
\hline & $(0.0067)$ & $(0.0071)$ \\
\hline \multirow[t]{2}{*}{ 2+ Kids in 1998} & $0.0382 * * *$ & $0.0324 * * *$ \\
\hline & $(0.0070)$ & $(0.0083)$ \\
\hline \multirow[t]{2}{*}{ 2+ Kids in 1999} & $0.0278 * * *$ & $0.0341 * * *$ \\
\hline & $(0.0076)$ & $(0.0100)$ \\
\hline \multirow[t]{2}{*}{ 2+ Kids in 2000} & $0.0425 * * *$ & $0.0295 * *$ \\
\hline & $(0.0075)$ & $(0.0123)$ \\
\hline \multirow[t]{2}{*}{2 Kids in Household } & $0.0337 * * *$ & -0.0102 \\
\hline & $(0.0055)$ & $(0.0151)$ \\
\hline \multirow[t]{2}{*}{3 Kids in Household } & $0.0606 * * *$ & -0.0042 \\
\hline & $(0.0094)$ & $(0.0275)$ \\
\hline \multirow[t]{2}{*}{4 Kids in Household } & $0.0799 * * *$ & 0.0135 \\
\hline & $(0.0137)$ & $(0.0393)$ \\
\hline \multirow[t]{2}{*}{5 Kids in Household } & $0.0897 * * *$ & 0.0413 \\
\hline & $(0.0182)$ & $(0.0508)$ \\
\hline \multirow[t]{2}{*}{6 Kids in Household } & $0.1132 * * *$ & 0.0859 \\
\hline & $(0.0232)$ & $(0.0616)$ \\
\hline \multirow[t]{2}{*}{7 Kids in Household } & $0.1607 * * *$ & $0.1293^{*}$ \\
\hline & $(0.0290)$ & $(0.0734)$ \\
\hline \multirow[t]{2}{*}{8 Kids in Household } & $0.2186 * * *$ & $0.1801^{* *}$ \\
\hline & $(0.0369)$ & $(0.0876)$ \\
\hline \multirow[t]{2}{*}{9 or More Kids in Household } & $0.2477 * * *$ & $0.2230 * *$ \\
\hline & $(0.0475)$ & $(0.1098)$ \\
\hline \multirow[t]{2}{*}{ No. of Kids Age 1} & $-0.1600 * * *$ & $-0.1206 * * *$ \\
\hline & $(0.0051)$ & $(0.0116)$ \\
\hline \multirow[t]{2}{*}{ No. of Kids Age 2} & $-0.1330 * * *$ & $-0.0888 * * *$ \\
\hline & $(0.0050)$ & $(0.0110)$ \\
\hline \multirow[t]{2}{*}{ No. of Kids Age 3} & $-0.1127 * * *$ & $-0.0653 * * *$ \\
\hline & $(0.0050)$ & $(0.0104)$ \\
\hline
\end{tabular}

(table continues) 
Table 3, continued

\begin{tabular}{|c|c|c|}
\hline$\underline{\text { Variable }}$ & $\begin{array}{c}\text { OLS, Repeated } \\
\text { Cross-Sectional Samples } \\
\end{array}$ & $\begin{array}{c}\text { Household Fixed } \\
\text { Effects, Panel Data }\end{array}$ \\
\hline No. of Kids Age 4 & $\begin{array}{l}-0.0926 * * * \\
(0.0050)\end{array}$ & $\begin{array}{l}-0.0455^{* * *} \\
(0.0099)\end{array}$ \\
\hline No. of Kids Age 5 & $\begin{array}{l}-0.0790 * * * \\
(0.0050)\end{array}$ & $\begin{array}{l}-0.0384 * * * \\
(0.0094)\end{array}$ \\
\hline No. of Kids Age 6 & $\begin{array}{l}-0.0685^{* * *} \\
(0.0050)\end{array}$ & $\begin{array}{l}-0.0320 * * * \\
(0.0090)\end{array}$ \\
\hline No. of Kids Age 7 & $\begin{array}{l}-0.0538 * * * \\
(0.0050)\end{array}$ & $\begin{array}{l}-0.0245^{* * *} \\
(0.0086)\end{array}$ \\
\hline No. of Kids Age 8 & $\begin{array}{l}-0.0496 * * * \\
(0.0051)\end{array}$ & $\begin{array}{l}-0.0239 * * * \\
(0.0082)\end{array}$ \\
\hline No. of Kids Age 9 & $\begin{array}{l}-0.0463 * * * \\
(0.0051)\end{array}$ & $\begin{array}{l}-0.0211^{* * *} \\
(0.0079)\end{array}$ \\
\hline No. of Kids Age 10 & $\begin{array}{l}-0.0431 * * * \\
(0.0052)\end{array}$ & $\begin{array}{l}-0.0201 * * * \\
(0.0076)\end{array}$ \\
\hline No. of Kids Age 11 & $\begin{array}{l}-0.0335^{* * *} \\
(0.0052)\end{array}$ & $\begin{array}{l}-0.0162 * * \\
(0.0073)\end{array}$ \\
\hline No. of Kids Age 12 & $\begin{array}{l}-0.0319 * * * \\
(0.0053)\end{array}$ & $\begin{array}{l}-0.0136 * * \\
(0.0069)\end{array}$ \\
\hline No. of Kids Age 13 & $\begin{array}{l}-0.0224 * * * \\
(0.0054)\end{array}$ & $\begin{array}{l}-0.0131 * * \\
(0.0066)\end{array}$ \\
\hline No. of Kids Age 14 & $\begin{array}{l}-0.0209 * * * \\
(0.0055)\end{array}$ & $\begin{array}{l}-0.0072 \\
(0.0063)\end{array}$ \\
\hline No. of Kids Age 15 & $\begin{array}{l}-0.0214^{* * *} \\
(0.0057)\end{array}$ & $\begin{array}{l}-0.0065 \\
(0.0060)\end{array}$ \\
\hline No. of Kids Age 16 & $\begin{array}{l}-0.0236 * * * \\
(0.0058)\end{array}$ & $\begin{array}{l}-0.0080 \\
(0.0057)\end{array}$ \\
\hline No. of Kids Age 17 & $-0.0166^{* * *}$ & $-0.0101 * *$ \\
\hline No. of Observations & 527,125 & $1,637,855$ \\
\hline P-Value for Test of $2+$ Kids in $1994-2000=0$ & 0.0000 & 0.0004 \\
\hline
\end{tabular}


Employment and EITC claiming are affected symmetrically by local labor market conditions. Both, not surprisingly, are positively correlated with county employment-to-population ratios and with the average earnings per worker in the county of residence. Residents of counties with high average manufacturing sector earnings have low employment and EITC claiming rates, suggesting that manufacturing companies are not primary employers of households in our sample.

\section{2 $\quad$ Tests 3 and 4: Employment Effects by Family Size and for Nonfilers}

The third test focuses on whether the differential employment trends observed in the data for one and two-or-more child families also hold for families with three or more children compared to two-child families. If the employment patterns are different for larger families, then factor other than the EITC likely are causing the employment differences documented in Table 3.

Column (1) in Table 5a repeats the fixed-effects estimates from Table 3. Column (2) shows the crucial "specification check" estimates. The coefficients on the [2+ Kids - 3+ Kids in $\mathrm{Yr}$ ] variables in column (2) are individually insignificant. Moreover, the bottom of the table reports the F-test, showing they are jointly insignificant. Thus, if something other than the EITC is causing employment rates of families with two or more children to increase by 3 percentage points relative to employment rates of onechild families in the second half of the 1990s, it must not differentially affect families with three or more children relative to two-child families. Table 5b shows similar patterns for EITC claiming.

In the fourth test, we restrict the sample to households that do not file tax returns. The sample is sizable, with 564,612 observations. ${ }^{36}$ Moreover, while these households do not file tax returns, a substantial fraction are employed on average in any given year (in the overall sample around 45 percent are employed). The results for this test are given in column (3) of Table 5a. There are no employment

\footnotetext{
${ }^{36}$ Of course in the fixed-effects specification, a given household can appear in the sample as many as four times. All standard errors reported in the paper are adjusted for the fact that the error term will not be independently distributed for observations that arise from the same household.
} 
Table 4

Estimates of EITC Effects on Whether Household Claimed the EITC on Tax Return

\begin{tabular}{|c|c|c|}
\hline Variable & $\begin{array}{c}\text { OLS, Repeated } \\
\text { Cross-Sectional Samples }\end{array}$ & $\begin{array}{c}\text { Household Fixed } \\
\text { Effects, Panel Data }\end{array}$ \\
\hline \multirow[t]{2}{*}{ 2+ Kids in 1994} & 0.0041 & 0.0006 \\
\hline & $(0.0059)$ & $(0.0038)$ \\
\hline \multirow[t]{2}{*}{ 2+ Kids in 1995} & -0.0032 & 0.0065 \\
\hline & $(0.0061)$ & $(0.0049)$ \\
\hline \multirow[t]{2}{*}{ 2+ Kids in 1996} & $0.0103^{*}$ & $0.0184 * * *$ \\
\hline & $(0.0062)$ & $(0.0058)$ \\
\hline \multirow[t]{2}{*}{ 2+ Kids in 1997} & 0.0050 & $0.0190 * * *$ \\
\hline & $(0.0066)$ & $(0.0068)$ \\
\hline \multirow[t]{2}{*}{ 2+ Kids in 1998} & $0.0249 * * *$ & $0.0170 * *$ \\
\hline & $(0.0070)$ & $(0.0081)$ \\
\hline \multirow[t]{2}{*}{ 2+ Kids in 1999} & $0.0283^{* * *}$ & $0.0233^{* *}$ \\
\hline & $(0.0077)$ & $(0.0098)$ \\
\hline \multirow[t]{2}{*}{ 2+ Kids in 2000} & $0.0448 * * *$ & 0.0194 \\
\hline & $(0.0076)$ & $(0.0122)$ \\
\hline \multirow[t]{2}{*}{2 Kids in Household } & $0.0351^{* * *}$ & $-0.0601 * * *$ \\
\hline & $(0.0051)$ & $(0.0143)$ \\
\hline \multirow[t]{2}{*}{3 Kids in Household } & $0.0532 * * *$ & $-0.1193 * * *$ \\
\hline & $(0.0089)$ & $(0.0261)$ \\
\hline \multirow[t]{2}{*}{4 Kids in Household } & $0.0593 * * *$ & $-0.1736 * * *$ \\
\hline & $(0.0130)$ & $(0.0373)$ \\
\hline \multirow[t]{2}{*}{5 Kids in Household } & $0.0591 * * *$ & $-0.2188 * * *$ \\
\hline & $(0.0175)$ & $(0.0484)$ \\
\hline \multirow[t]{2}{*}{6 Kids in Household } & $0.0728 * * *$ & $-0.2535 * * *$ \\
\hline & $(0.0222)$ & $(0.0587)$ \\
\hline \multirow[t]{2}{*}{7 Kids in Household } & $0.1093^{* * *}$ & $-0.3096 * * *$ \\
\hline & $(0.0278)$ & $(0.0697)$ \\
\hline \multirow[t]{2}{*}{8 Kids in Household } & $0.1197 * * *$ & $-0.2874 * * *$ \\
\hline & $(0.0351)$ & $(0.0833)$ \\
\hline \multirow[t]{2}{*}{9 or More Kids in Household } & $0.1830 * * *$ & $-0.2442 * *$ \\
\hline & $(0.0448)$ & $(0.1044)$ \\
\hline \multirow[t]{2}{*}{ No. of Kids Age 1} & $-0.1153 * * *$ & -0.0093 \\
\hline & $(0.0049)$ & $(0.0110)$ \\
\hline \multirow[t]{2}{*}{ No. of Kids Age 2} & $-0.0971 * * *$ & 0.0072 \\
\hline & $(0.0048)$ & $(0.0104)$ \\
\hline
\end{tabular}

(table continues) 
Table 4, continued

\begin{tabular}{|c|c|c|}
\hline Variable & $\begin{array}{c}\text { OLS, Repeated } \\
\text { Cross-Sectional Samples }\end{array}$ & $\begin{array}{c}\text { Household Fixed } \\
\text { Effects, Panel Data }\end{array}$ \\
\hline \multirow[t]{2}{*}{ No. of Kids Age 3} & $-0.0762 * * *$ & $0.0200 * *$ \\
\hline & $(0.0048)$ & $(0.0099)$ \\
\hline \multirow[t]{2}{*}{ No. of Kids Age 4} & $-0.0671 * * *$ & $0.0280 * * *$ \\
\hline & $(0.0047)$ & $(0.0094)$ \\
\hline \multirow[t]{2}{*}{ No. of Kids Age 5} & $-0.0541 * * *$ & $0.0294 * * *$ \\
\hline & $(0.0048)$ & $(0.0090)$ \\
\hline \multirow[t]{2}{*}{ No. of Kids Age 6} & $-0.0434 * * *$ & $0.0308 * * *$ \\
\hline & $(0.0048)$ & $(0.0086)$ \\
\hline \multirow[t]{2}{*}{ No. of Kids Age 7} & $-0.0340 * * *$ & $0.0330 * * *$ \\
\hline & $(0.0048)$ & $(0.0082)$ \\
\hline \multirow[t]{2}{*}{ No. of Kids Age 8} & $-0.0316^{* * *}$ & $0.0316 * * *$ \\
\hline & $(0.0049)$ & $(0.0079)$ \\
\hline \multirow[t]{2}{*}{ No. of Kids Age 9} & $-0.0287 * * *$ & $0.0312 * * *$ \\
\hline & $(0.0049)$ & $(0.0076)$ \\
\hline \multirow[t]{2}{*}{ No. of Kids Age 10} & $-0.0241 * * *$ & $0.0301 * * *$ \\
\hline & $(0.0050)$ & $(0.0073)$ \\
\hline \multirow[t]{2}{*}{ No. of Kids Age 11} & $-0.0200 * * *$ & $0.0298 * * *$ \\
\hline & $(0.0050)$ & $(0.0070)$ \\
\hline \multirow[t]{2}{*}{ No. of Kids Age 12} & $-0.0212 * * *$ & $0.0300 * * *$ \\
\hline & $(0.0051)$ & $(0.0067)$ \\
\hline \multirow[t]{2}{*}{ No. of Kids Age 13} & $-0.0103 * *$ & $0.0270 * * *$ \\
\hline & $(0.0052)$ & $(0.0064)$ \\
\hline \multirow[t]{2}{*}{ No. of Kids Age 14} & $-0.0109 * *$ & $0.0251 * * *$ \\
\hline & $(0.0053)$ & $(0.0061)$ \\
\hline \multirow[t]{2}{*}{ No. of Kids Age 15} & $-0.0163 * * *$ & $0.0205 * * *$ \\
\hline & $(0.0054)$ & $(0.0058)$ \\
\hline \multirow{2}{*}{ No. of Kids Age 16} & $-0.0152 * * *$ & $0.0147 * * *$ \\
\hline & $(0.0055)$ & $(0.0055)$ \\
\hline \multirow[t]{2}{*}{ No. of Kids Age 17} & -0.0037 & $0.0088^{*}$ \\
\hline & $(0.0055)$ & $(0.0049)$ \\
\hline No. of Observations & 527,125 & $1,637,855$ \\
\hline P-Value for Test of $2+$ Kids in 1994-2000 $=0$ & 0.0000 & 0.0353 \\
\hline
\end{tabular}


differences between families with one child, two children, or three or more children. Thus, whatever is causing increases in the employment of families with two or more children relative to one-child families, it only occurs for those who file tax returns.

We think the most sensible interpretation of the evidence from the four-part test is that the EITC is responsible for the differential employment increase of families with two or more children relative to one-child families.

\subsection{Other Sensitivity Analyses ${ }^{37}$}

Empirical projects inevitably require judgments about model specification. In the following subsection, we briefly discuss the consequences of making different modeling assumptions.

\subsubsection{Altering the Base Year Definition}

In all specifications presented to this point, we use average employment or average EITC claiming between 1991 and 1993 as the reference period for the regressions. We do this because the maximum EITC differential between families with two or more children and one child was inconsequentially different from $\$ 0$ during these years. But pooling the reference period masks another subtle specification check for our model. Namely, there should be no significant employment (or EITC claiming) trends prior to the period when the EITC began to diverge for the two groups of households. Unfortunately, because data are not available prior to 1991, we cannot go back further to examine employment and EITC claiming trends.

There is no evidence of employment trends between 1991-1993. In the fixed-effects employment specifications shown in Table 5c, for example, the coefficient (standard error) on the " $2+$ Kids in 1991"

\footnotetext{
${ }^{37}$ Complete results for every specification discussed in this section are available from the authors on request. In the interest of space, we provide only summary results in the tables and discussion that follows.
} 
Table 5a

Assessing the Validity of Strategy for Identifying EITC Effects on Household Employment (Family Fixed-Effects Estimation on Panel Data)

\begin{tabular}{|c|c|c|c|}
\hline \multirow[b]{2}{*}{ Variable } & \multicolumn{2}{|c|}{ All Households } & \multirow{2}{*}{$\begin{array}{l}\text { Households that Did } \\
\text { Not File Tax Return } \\
\text { (3) }\end{array}$} \\
\hline & $(1)$ & $(2)$ & \\
\hline 2+ Kids in 1994 & $\begin{array}{l}-0.0035 \\
(0.0041)\end{array}$ & $\begin{array}{l}-0.0016 \\
(0.0051)\end{array}$ & $\begin{array}{l}-0.0020 \\
(0.0065)\end{array}$ \\
\hline 2+ Kids in 1995 & $\begin{array}{c}0.0072 \\
(0.0052)\end{array}$ & $\begin{array}{c}0.0043 \\
(0.0067)\end{array}$ & $\begin{array}{c}0.0028 \\
(0.0086)\end{array}$ \\
\hline 2+ Kids in 1996 & $\begin{array}{l}0.0123^{* *} \\
(0.0061)\end{array}$ & $\begin{array}{c}0.0114 \\
(0.0082)\end{array}$ & $\begin{array}{l}-0.0016 \\
(0.0107)\end{array}$ \\
\hline 2+ Kids in 1997 & $\begin{array}{l}0.0261^{* * *} \\
(0.0071)\end{array}$ & $\begin{array}{l}0.0289 * * * \\
(0.0098)\end{array}$ & $\begin{array}{c}0.0113 \\
(0.0131)\end{array}$ \\
\hline 2+ Kids in 1998 & $\begin{array}{l}0.0324^{* * *} \\
(0.0083)\end{array}$ & $\begin{array}{l}0.0331^{* * *} \\
(0.0116)\end{array}$ & $\begin{array}{c}0.0048 \\
(0.0161)\end{array}$ \\
\hline 2+ Kids in 1999 & $\begin{array}{l}0.0341^{* * *} \\
(0.0100)\end{array}$ & $\begin{array}{l}0.0368 * * * \\
(0.0137)\end{array}$ & $\begin{array}{c}0.0037 \\
(0.0200)\end{array}$ \\
\hline $2+$ Kids in 2000 & $\begin{array}{l}0.0295 * * \\
(0.0123)\end{array}$ & $\begin{array}{c}0.0291^{*} \\
(0.0168)\end{array}$ & $\begin{array}{l}-0.0009 \\
(0.0257)\end{array}$ \\
\hline [2+ Kids - 3+ Kids] in 1994 & & $\begin{array}{l}-0.0030 \\
(0.0051)\end{array}$ & $\begin{array}{l}-0.0009 \\
(0.0062)\end{array}$ \\
\hline [2+ Kids - 3+ Kids] in 1995 & & $\begin{array}{c}0.0055 \\
(0.0063)\end{array}$ & $\begin{array}{l}-0.0010 \\
(0.0080)\end{array}$ \\
\hline [2+ Kids - 3+ Kids] in 1996 & & $\begin{array}{c}0.0021 \\
(0.0074)\end{array}$ & $\begin{array}{l}-0.0014 \\
(0.0096)\end{array}$ \\
\hline [2+ Kids - 3+ Kids] in 1997 & & $\begin{array}{l}-0.0042 \\
(0.0086)\end{array}$ & $\begin{array}{l}-0.0012 \\
(0.0115)\end{array}$ \\
\hline [2+ Kids - 3+ Kids] in 1998 & & $\begin{array}{l}-0.0004 \\
(0.0100)\end{array}$ & $\begin{array}{c}0.0005 \\
(0.0141)\end{array}$ \\
\hline [2+ Kids - 3+ Kids] in 1999 & & $\begin{array}{l}-0.0039 \\
(0.0119)\end{array}$ & $\begin{array}{l}-0.0071 \\
(0.0181)\end{array}$ \\
\hline [2+ Kids - 3+ Kids] in 2000 & & $\begin{array}{c}0.0015 \\
(0.0149)\end{array}$ & $\begin{array}{c}0.0077 \\
(0.0244)\end{array}$ \\
\hline No. of Observations & & & \\
\hline P-Value for Test of $2+$ Kids in 1994-2000 $=0$ & 0.0004 & 0.0112 & 0.8423 \\
\hline $\begin{array}{l}\text { P-Value for Test of }[2+\text { Kids }-3+\text { Kids }] \text { in } \\
1994-2000=0\end{array}$ & & 0.7389 & 0.9989 \\
\hline
\end{tabular}


Table 5b

Assessing the Validity of Strategy for Identifying

EITC Effects on Whether Household Claimed the EITC on Tax Return

(Family Fixed-Effects Estimation on Panel Data)

\begin{tabular}{|c|c|c|}
\hline Variable & $(1)$ & $(2)$ \\
\hline 2+ Kids in 1994 & $\begin{array}{c}0.0006 \\
(0.0038)\end{array}$ & $\begin{array}{c}0.0057 \\
(0.0048)\end{array}$ \\
\hline 2+ Kids in 1995 & $\begin{array}{c}0.0065 \\
(0.0049)\end{array}$ & $\begin{array}{c}0.0131^{* *} \\
(0.0064)\end{array}$ \\
\hline 2+ Kids in 1996 & $\begin{array}{l}0.0184^{* * *} \\
(0.0058)\end{array}$ & $\begin{array}{l}0.0233^{* * *} \\
(0.0078)\end{array}$ \\
\hline 2+ Kids in 1997 & $\begin{array}{l}0.0190^{* * *} \\
(0.0068)\end{array}$ & $\begin{array}{l}0.0279 * * * \\
(0.0094)\end{array}$ \\
\hline 2+ Kids in 1998 & $\begin{array}{l}0.0170^{* *} \\
(0.0081)\end{array}$ & $\begin{array}{c}0.0170 \\
(0.0112)\end{array}$ \\
\hline 2+ Kids in 1999 & $\begin{array}{l}0.0233^{* *} \\
(0.0098)\end{array}$ & $\begin{array}{l}0.0344^{* *} \\
(0.0134)\end{array}$ \\
\hline 2+ Kids in 2000 & $\begin{array}{c}0.0194 \\
(0.0122)\end{array}$ & $\begin{array}{c}0.0255 \\
(0.0165)\end{array}$ \\
\hline [2+ Kids - 3+ Kids] in 1994 & & $\begin{array}{l}-0.0078 * \\
(0.0047)\end{array}$ \\
\hline [2+ Kids - 3+ Kids] in 1995 & & $\begin{array}{l}-0.0100 * \\
(0.0059)\end{array}$ \\
\hline [2+ Kids - 3+ Kids] in 1996 & & $\begin{array}{l}-0.0067 \\
(0.0070)\end{array}$ \\
\hline [2+ Kids - 3+ Kids] in 1997 & & $\begin{array}{l}-0.0131 \\
(0.0082)\end{array}$ \\
\hline [2+ Kids - 3+ Kids] in 1998 & & $\begin{array}{c}0.0033 \\
(0.0097)\end{array}$ \\
\hline [2+ Kids - 3+ Kids] in 1999 & & $\begin{array}{l}-0.0158 \\
(0.0119)\end{array}$ \\
\hline [2+ Kids $-3+$ Kids] in 2000 & & $\begin{array}{l}-0.0063 \\
(0.0149)\end{array}$ \\
\hline P-Value for Test of $2+$ Kids in 1994-2000 $=0$ & 0.0353 & 0.0174 \\
\hline P-Value for Test of $[2+$ Kids $-3+$ Kids $]$ in 1994-2000 $=0$ & & 0.0669 \\
\hline
\end{tabular}


Table 5c

Estimates of EITC Effects on Household Employment Using 1992 as Base Year (Family Fixed-Effects Estimation on Panel Data)

\begin{tabular}{|c|c|c|}
\hline Variable & (1) & (1) \\
\hline \multirow[t]{2}{*}{ 2+ Kids in 1991} & -0.0040 & -0.0040 \\
\hline & $(0.0043)$ & $(0.0053)$ \\
\hline \multirow[t]{2}{*}{ 2+ Kids in 1993} & 0.0008 & -0.0001 \\
\hline & $(0.0042)$ & $(0.0051)$ \\
\hline \multirow[t]{2}{*}{ 2+ Kids in 1994} & -0.0031 & -0.0012 \\
\hline & $(0.0052)$ & $(0.0068)$ \\
\hline \multirow[t]{2}{*}{ 2+ Kids in 1995} & 0.0079 & 0.0054 \\
\hline & $(0.0061)$ & $(0.0084)$ \\
\hline \multirow[t]{2}{*}{ 2+ Kids in 1996} & $0.0132 *$ & 0.0130 \\
\hline & $(0.0070)$ & $(0.0100)$ \\
\hline \multirow[t]{2}{*}{ 2+ Kids in 1997} & $0.0272 * * *$ & $0.0310 * * *$ \\
\hline & $(0.0079)$ & $(0.0117)$ \\
\hline \multirow[t]{2}{*}{ 2+ Kids in 1998} & $0.0337 * * *$ & $0.0357 * * *$ \\
\hline & $(0.0091)$ & $(0.0136)$ \\
\hline \multirow{2}{*}{ 2+ Kids in 1999} & $0.0357 * * *$ & $0.0400 * *$ \\
\hline & $(0.0108)$ & $(0.0159)$ \\
\hline \multirow[t]{2}{*}{ 2+ Kids in 2000} & $0.0314^{* *}$ & $0.0330 *$ \\
\hline & $(0.0130)$ & $(0.0191)$ \\
\hline \multirow[t]{2}{*}{ [2+ Kids - 3+ Kids] in 1991} & & -0.0005 \\
\hline & & $(0.0052)$ \\
\hline \multirow[t]{2}{*}{ [2+ Kids - 3+ Kids] in 1993} & & 0.0018 \\
\hline & & $(0.0051)$ \\
\hline \multirow{2}{*}{ [2+ Kids - 3+ Kids] in 1994} & & -0.0027 \\
\hline & & $(0.0065)$ \\
\hline \multirow[t]{2}{*}{ [2+ Kids - 3+ Kids] in 1995} & & 0.0056 \\
\hline & & $(0.0076)$ \\
\hline \multirow[t]{2}{*}{ [2+ Kids - 3+ Kids] in 1996} & & 0.0018 \\
\hline & & $(0.0088)$ \\
\hline \multirow[t]{2}{*}{ [2+ Kids - 3+ Kids] in 1997} & & -0.0049 \\
\hline & & $(0.0099)$ \\
\hline \multirow[t]{2}{*}{ [2+ Kids - 3+ Kids] in 1998} & & -0.0015 \\
\hline & & $(0.0114)$ \\
\hline \multirow[t]{2}{*}{ [2+ Kids - 3+ Kids] in 1999} & & -0.0054 \\
\hline & & $(0.0133)$ \\
\hline \multirow[t]{2}{*}{ [2+ Kids $-3+$ Kids] in 2000} & & -0.0004 \\
\hline & & $(0.0163)$ \\
\hline P-Value for Test of 2+ Kids 1994-2000 $=0$ & 0.0003 & 0.0088 \\
\hline P-Value for Test of $2+$ Kids in $1991 \& 1993=0$ & 0.6069 & \\
\hline P-Value for Test of $[2+$ Kids $-3+$ Kids $]$ for $1994-2000=0$ & & 0.7373 \\
\hline
\end{tabular}




\begin{tabular}{|c|c|c|c|c|}
\hline \multicolumn{5}{|c|}{ 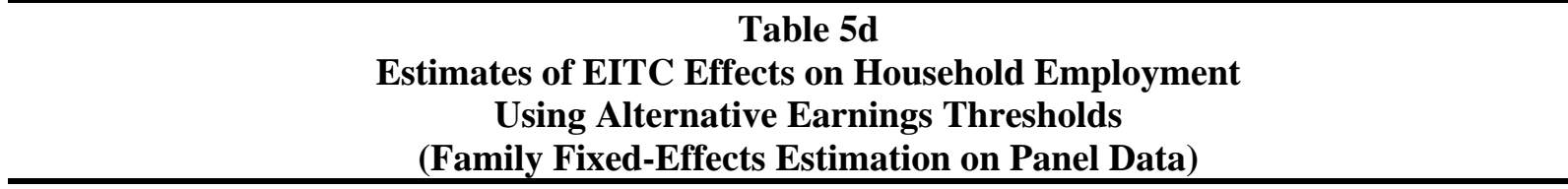 } \\
\hline \multirow[b]{2}{*}{ Variable } & \multicolumn{2}{|c|}{$\begin{array}{l}\text { Household Employment }=1 \\
\text { If Earnings }>\$ 500\end{array}$} & \multicolumn{2}{|c|}{$\begin{array}{l}\text { Household Employment }=1 \\
\text { If Earnings }>\$ 1,000\end{array}$} \\
\hline & $(1)$ & $(2)$ & $(3)$ & $(4)$ \\
\hline 2+ Kids in 1994 & $\begin{array}{l}-0.0015 \\
(0.0040)\end{array}$ & $\begin{array}{l}-0.0007 \\
(0.0049)\end{array}$ & $\begin{array}{l}-0.0039 \\
(0.0039)\end{array}$ & $\begin{array}{l}-0.0030 \\
(0.0047)\end{array}$ \\
\hline 2+ Kids in 1995 & $\begin{array}{c}0.0063 \\
(0.0050)\end{array}$ & $\begin{array}{c}0.0032 \\
(0.0065)\end{array}$ & $\begin{array}{c}0.0037 \\
(0.0049)\end{array}$ & $\begin{array}{c}0.0026 \\
(0.0063)\end{array}$ \\
\hline 2+ Kids in 1996 & $\begin{array}{l}0.0130 * * \\
(0.0060)\end{array}$ & $\begin{array}{c}0.0090 \\
(0.0079)\end{array}$ & $\begin{array}{c}0.0101^{*} \\
(0.0059)\end{array}$ & $\begin{array}{c}0.0067 \\
(0.0077)\end{array}$ \\
\hline 2+ Kids in 1997 & $\begin{array}{l}0.0217^{* * *} \\
(0.0070)\end{array}$ & $\begin{array}{l}0.0216^{* *} \\
(0.0095)\end{array}$ & $\begin{array}{l}0.0176^{* * *} \\
(0.0068)\end{array}$ & $\begin{array}{c}0.0159 * \\
(0.0092)\end{array}$ \\
\hline 2+ Kids in 1998 & $\begin{array}{l}0.0331^{* * *} \\
(0.0082)\end{array}$ & $\begin{array}{l}0.0268 * * \\
(0.0113)\end{array}$ & $\begin{array}{l}0.0264^{* * *} \\
(0.0081)\end{array}$ & $\begin{array}{l}0.0225^{* *} \\
(0.0110)\end{array}$ \\
\hline 2+ Kids in 1999 & $\begin{array}{l}0.0308^{* * *} \\
(0.0100)\end{array}$ & $\begin{array}{c}0.0241^{*} \\
(0.0134)\end{array}$ & $\begin{array}{l}0.0201^{* *} \\
(0.0098)\end{array}$ & $\begin{array}{c}0.0141 \\
(0.0131)\end{array}$ \\
\hline 2+ Kids in 2000 & $\begin{array}{c}0.0259 * * \\
(0.0123)\end{array}$ & $\begin{array}{c}0.0195 \\
(0.0164)\end{array}$ & $\begin{array}{c}0.0141 \\
(0.0121)\end{array}$ & $\begin{array}{c}0.0065 \\
(0.0162)\end{array}$ \\
\hline [2+ Kids - 3+ Kids] in 1994 & & $\begin{array}{l}-0.0025 \\
(0.0049)\end{array}$ & & $\begin{array}{l}-0.0027 \\
(0.0047)\end{array}$ \\
\hline [2+ Kids - 3+ Kids] in 1995 & & $\begin{array}{c}0.0037 \\
(0.0061)\end{array}$ & & $\begin{array}{c}0.0002 \\
(0.0059)\end{array}$ \\
\hline [2+ Kids - 3+ Kids] in 1996 & & $\begin{array}{c}0.0045 \\
(0.0072)\end{array}$ & & $\begin{array}{c}0.0035 \\
(0.0070)\end{array}$ \\
\hline [2+ Kids - 3+ Kids] in 1997 & & $\begin{array}{l}-0.0031 \\
(0.0083)\end{array}$ & & $\begin{array}{l}-0.0002 \\
(0.0081)\end{array}$ \\
\hline [2+ Kids - 3+ Kids] in 1998 & & $\begin{array}{c}0.0073 \\
(0.0097)\end{array}$ & & $\begin{array}{c}0.0033 \\
(0.0095)\end{array}$ \\
\hline [2+ Kids - 3+ Kids] in 1999 & & $\begin{array}{c}0.0076 \\
(0.0118)\end{array}$ & & $\begin{array}{c}0.0064 \\
(0.0116)\end{array}$ \\
\hline [2+ Kids - 3+ Kids] in 2000 & & $\begin{array}{c}0.0063 \\
(0.0147)\end{array}$ & & $\begin{array}{c}0.0086 \\
(0.0146)\end{array}$ \\
\hline $\begin{array}{l}\text { P-Value for Test of } 2+\text { Kids for } \\
1994-2000=0\end{array}$ & 0.0026 & 0.1482 & 0.0083 & 0.1636 \\
\hline $\begin{array}{l}\text { P-Value for Test of [2+ Kids }-3+ \\
\text { Kids] for } 1994-2000=0\end{array}$ & & 0.6594 & & 0.9676 \\
\hline
\end{tabular}


variable is $-.004(.004)$ and the coefficient (standard error) on the [2+ Kids - 3+ Kids in 1993] variable is $.0008(.0042)$.

\subsubsection{Altering the Definition of Employment}

In our analysis thus far, we have classified a household as being employed if it reported having any labor market earnings reported to the UI system in a given year. One may not think that a household that only earns a hundred dollars or so in the labor market is really employed when thinking about the economic importance of the effects documented in this paper. To address this concern, we estimated our fixed-effects empirical models defining employment as having earnings exceeding \$500 in the year (the left-hand panel of Table 5d), and as having earnings exceeding \$1,000 in the year (the right-hand panel of Table 5d).

The patterns are similar to the baseline estimates. The consequence of increasing the earnings threshold above which we define a household as being "employed" is that the magnitude and the significance of the coefficient estimates decreases somewhat as the threshold is increased.

\subsubsection{Focus on AFDC-UP Cases}

It is well known that the EITC can have negative employment incentives on the intensive margin for married couples if one partner's earnings place the couple in the phaseout range of the credit (see, for example, Eissa and Hoynes, 2004). For our analysis, however, we define employment as the first dollar of the couple's earnings, so by this definition, the credit still has unambiguously positive employment incentives (on the extensive margin). Roughly 70 percent of the AFDC-UP cases, i.e., cases on welfare with two (unemployed) parents, have some earnings in a given year.

We find no evidence that the differential expansion of the EITC for families with two or more children increased employment of adults in AFDC-UP households. In the fixed-effects empirical models (equation 5), the “2+ Kids” by year interaction terms are all individually and jointly insignificant. If we look more closely at employment patterns by the number of children, it looks like the economy or welfare reform or some other factor perhaps began to affect the employment of AFDC-UP families in 1999 and 
2000, and these influences had larger effects for families with three or more children. But the patterns are not what one would expect to see if the EITC were the factor causing the changes.

\subsubsection{Can Changes in Child Care Spending Explain the Employment Trends for Single-Parent Families?}

Public expenditures for child care were quite low for most of the period we examine in the paper.

But late in the 1990s, state child care spending increased sharply (Marrufo, O’Brien-Strain, Oliver, 2003).

This also is the period when the employment of single parents with two or more children increased

relative to parents with one child. Moreover, the increases come after the differential EITC expansions, which raises the question of whether some other factor is causing the patterns observed in the data. To some extent we have already discussed this issue, because the changes would need to affect employment of families with two or more children relative to one-child families, but not affect employment of families with three or more children relative to two-child families. It is unlikely that child care expenditure increases would have this empirical pattern. But it is nevertheless straightforward to include a measure of county (public) child care expenditures for the welfare caseload in our empirical fixed-effects regression models of employment.

Two results stand out from this alternative specification. First, the central coefficients on employment are unchanged (they actually get slightly larger). The coefficients on the specification check terms remain insignificant, individually and jointly. Second, the estimated coefficient on the child care variable is consistently negative and precisely estimated. We think the most likely explanation for this finding is "policy endogeneity." Counties with more severe employment problems, particularly in the late 1990s after a decade-long economic expansion, implemented more aggressive child care subsidy programs. This response by counties would account for the negative correlation between child care spending and employment that we find in our data. Regardless of the explanation, the expansion of child care spending does not account for the differential employment patterns by number of children documented in this paper. 


\section{CONCLUSIONS}

The EITC transfers a large amount of money to working poor families and reduces poverty. There is also a considerable amount of evidence that the credit not only redistributes resources, but also encourages employment, thereby avoiding one of the negative behavioral incentives of traditional income transfer programs. No previous EITC employment study, however, has used data on whether or not people eligible for the EITC actually file tax returns and claim it. Our analysis of tax data reinforce the finding that the EITC appears to positively influence employment. Patterns of EITC claiming appear to mirror employment patterns in the data. Consistent with the nature of the expansion of the EITC by number of qualifying children in the 1990s, we only find differences in employment between families with two or more children relative to one-child families, and not between families with three or more children relative to two-child families. This result rules out alternative explanations that imply that employment should increase (or decrease) with the number of children in a household. Moreover, we find no EITC-like employment effects in samples where households do not file tax returns.

In addition to having access to tax data, our work also adds several distinctive features to the EITC employment literature. We use a different identification strategy than most papers on the topic, where we compare employment rates of families with two or more children to employment rates of onechild families over a period where the EITC increases more rapidly for families with two or more children. We estimate our empirical model with longitudinal data, which allow us to account for timeinvariant characteristics of households that may affect employment. And our analysis is based on California, which allows us to account in a detailed way for local labor market and transfer program characteristics that likely affect employment.

We also focus on the portion of the population that is of considerable interest to policymakers: women with children who are trying to make the transition from welfare to work. Existing studies typically focus on single mothers using data from the Current Population Survey (CPS) and the Survey of Income and Program Participation. But labor force participation rates of single mothers in the CPS are 
around 80 percent. Labor force participation rates in our sample of welfare recipients start around 35 percent. Around 28 percent of single mothers in the CPS receive welfare. All households in our sample received welfare at some point. Our results indicate that the positive employment effects of the EITC for single mothers documented in other studies also apply to the more economically disadvantaged population of welfare recipients.

By documenting the regression-adjusted pattern of employment changes by year for families with two or more children relative to one-child families, we provide new evidence that the employment responses to EITC policy changes occur with a lag of one or two years.

Our preferred estimates from Table 3 suggest that the differential EITC expansions increased employment by as much as 3.4 percentage points for families with two or more children relative to families with one child. As shown in Table 2, overall employment rates increased between 1991 and 2000 by 26.6 percentage points for one-child families and by 31 percentage points for families with two or more children. The average employment increase for the two groups was 28.8 percentage points: the differential EITC expansion accounted for 11.8 percent of the average increase in employment over this period. This would seem somewhat smaller than what is implied by the Meyer and Rosenbaum (2001) and Grogger (2003) results. ${ }^{38}$ But this illustrative calculation may provide an unduly pessimistic view of the EITC. The EITC expanded for all families with children over this time period. The differential EITC expansion can explain, in the regression-adjusted fixed-effects specification, 77 percent of the difference in the change of employment between families with two or more children and one-child families.

Another way of assessing the magnitude and consequences of our estimated effects of the EITC is to examine the implied elasticity of employment with respect to a household's disposable income. Hotz, Mullin, and Scholz (2002a) report that average annual disposable income for single-parent welfare cases

\footnotetext{
${ }^{38}$ Meyer and Rosenbaum (2001) find that EITC changes account for roughly 60 percent of the increase in the employment rate of single mothers from 1984 to 1996 and roughly 31 percent of the increase from 1992 to 1996. Grogger's (2003) conclusion is quoted in footnote 4.
} 
in their four-county California sample in 1998 was around $\$ 10,000 .^{39}$ The average EITC differential for families with one and two or more children in their sample was \$439 in 1998. Hence, the EITC increased disposable income by roughly 4.4 percent. Employment rates for families with two or more children in 1998 were around 60 percent, and the EITC expansion increased employment of families with two or more children by 3.2 percentage points, or 5.6 percent (3.2/(60-3.2)). This implies an employment elasticity with respect to disposable income of 1.3, which is at the upper end of the range of such estimates for the previous studies of the employment effects of the EITC discussed in Hotz and Scholz (2003).

Carrying the back-of-envelope calculation further, a \$439 relative increase in the EITC for families with two or more children resulted in a 3.2 percentage-point increase in employment. For onechild families, the average EITC receipt increased by $\$ 677$ between 1993 and 1998, at least partly as a consequence of legislated EITC expansions in 1990 and 1993. If the estimated employment effects are linear (in the sense that a $\$ 439$ effective increase in the EITC increases employment by 3.2 percentage points), the EITC can account for 21 percent of the 23.4 percentage-point increase in employment of onechild families between 1993 and 1998. Similar calculations imply that EITC can account for 29 percent of the 28.1 percentage-point increase in employment for families with two or more children.

Our paper shows that the EITC can be an important tool in efforts to increase employment of welfare recipients.

\footnotetext{
${ }^{39}$ The data for Hotz, Mullin, Scholz (2002a, 2002b) was similar to that used for this study, but came from only four counties (Alameda, Los Angeles, San Bernardino, and San Joaquin).
} 
Appendix Table 1a

Weighted Descriptive Statistics for the Repeated Cross-Sectional Analysis Samples $(N=527,125)$

\begin{tabular}{|c|c|c|c|c|c|}
\hline Variable & & Mean & Std Dev & Min & Max \\
\hline \multicolumn{6}{|c|}{ Outcome variables of interest: } \\
\hline Emp & $\begin{array}{l}\text { Household employed in year (= 1if at least } 1 \text { adult employed; = } 0 \\
\text { otherwise) }\end{array}$ & 0.477 & 0.499 & 0 & 1 \\
\hline FiledTax & Household filed tax return in year ( $=1$ yes; $=0$ no) & 0.425 & 0.494 & 0 & 1 \\
\hline ClaimEITC & Household filed tax return and claimed EITC in year $(=1$, yes; $=0$, no $)$ & 0.351 & 0.477 & 0 & 1 \\
\hline \multicolumn{6}{|l|}{ Calendar Year Indicators: } \\
\hline Year_1991 & Year $=1991$ & 0.120 & 0.325 & 0 & 1 \\
\hline Year_1992 & Year $=1992$ & 0.106 & 0.307 & 0 & 1 \\
\hline Year_1993 & Year $=1993$ & 0.098 & 0.297 & 0 & 1 \\
\hline Year_1994 & Year $=1994$ & 0.102 & 0.302 & 0 & 1 \\
\hline Year_1995 & Year $=1995$ & 0.105 & 0.307 & 0 & 1 \\
\hline Year_1996 & Year = 1996 & 0.105 & 0.307 & 0 & 1 \\
\hline Year_1997 & Year $=1997$ & 0.102 & 0.302 & 0 & 1 \\
\hline Year_1998 & Year $=1998$ & 0.093 & 0.290 & 0 & 1 \\
\hline Year_1999 & Year = 1999 & 0.079 & 0.270 & 0 & 1 \\
\hline Year_2000 & Year $=2000$ & 0.091 & 0.288 & 0 & 1 \\
\hline \multicolumn{6}{|c|}{ Treatment and "Testing" Variables: } \\
\hline 2+ Kids in 1991 & Household had 2 or more kids in 1991 & 0.066 & 0.248 & 0 & 1 \\
\hline 2+ Kids in 1992 & Household had 2 or more kids in 1992 & 0.057 & 0.231 & 0 & 1 \\
\hline 2+ Kids in 1993 & Household had 2 or more kids in 1993 & 0.052 & 0.221 & 0 & 1 \\
\hline 2+ Kids in 1994 & Household had 2 or more kids in 1994 & 0.054 & 0.225 & 0 & 1 \\
\hline 2+ Kids in 1995 & Household had 2 or more kids in 1995 & 0.055 & 0.228 & 0 & 1 \\
\hline 2+ Kids in 1996 & Household had 2 or more kids in 1996 & 0.054 & 0.226 & 0 & 1 \\
\hline 2+ Kids in 1997 & Household had 2 or more kids in 1997 & 0.052 & 0.222 & 0 & 1 \\
\hline 2+ Kids in 1998 & Household had 2 or more kids in 1998 & 0.047 & 0.211 & 0 & 1 \\
\hline 2+ Kids in 1999 & Household had 2 or more kids in 1999 & 0.040 & 0.196 & 0 & 1 \\
\hline 2+ Kids in 2000 & Household had 2 or more kids in 2000 & 0.046 & 0.211 & 0 & 1 \\
\hline [2+ Kids-3+ Kids] in 1991 & Household had exactly two children in 1991 & 0.038 & 0.191 & 0 & 1 \\
\hline [2+ Kids-3+ Kids] in 1992 & Household had exactly two children in 1992 & 0.032 & 0.176 & 0 & 1 \\
\hline [2+ Kids-3+ Kids] in 1993 & Household had exactly two children in 1993 & 0.029 & 0.169 & 0 & 1 \\
\hline
\end{tabular}


Appendix Table 1a, continued

\begin{tabular}{|c|c|c|c|c|c|}
\hline Variable & & Mean & Std Dev & Min & Max \\
\hline [2+ Kids-3+ Kids] in 1994 & Household had exactly two children in 1994 & 0.031 & 0.172 & 0 & 1 \\
\hline [2+ Kids-3+ Kids] in 1995 & Household had exactly two children in 1995 & 0.032 & 0.176 & 0 & 1 \\
\hline [2+ Kids-3+ Kids] in 1996 & Household had exactly two children in 1996 & 0.031 & 0.174 & 0 & 1 \\
\hline [2+ Kids-3+ Kids] in 1997 & Household had exactly two children in 1997 & 0.030 & 0.171 & 0 & 1 \\
\hline [2+ Kids-3+ Kids] in 1998 & Household had exactly two children in 1998 & 0.027 & 0.162 & 0 & 1 \\
\hline [2+ Kids-3+ Kids] in 1999 & Household had exactly two children in 1999 & 0.023 & 0.150 & 0 & 1 \\
\hline [2+ Kids-3+ Kids] in 2000 & Household had exactly two children in 2000 & 0.027 & 0.161 & 0 & 1 \\
\hline \multicolumn{6}{|l|}{ Number and Ages of Children: } \\
\hline 1 Kid in Household & Household has 1 child $(=1$, yes; $=0$, no) & 0.478 & 0.499 & 0 & 1 \\
\hline 2 Kids in Household & Household has 2 children $(=1$, yes; $=0$, no $)$ & 0.300 & 0.458 & 0 & 1 \\
\hline 3 Kids in Household & Household has 3 children $(=1$, yes; $=0$, no $)$ & 0.142 & 0.349 & 0 & 1 \\
\hline 4 Kids in Household & Household has 4 children $(=1$, yes; $=0$, no $)$ & 0.053 & 0.225 & 0 & 1 \\
\hline 5 Kids in Household & Household has 5 children $(=1$, yes; $=0$, no $)$ & 0.018 & 0.132 & 0 & 1 \\
\hline 6 Kids in Household & Household has 6 children $(=1$, yes; $=0$, no $)$ & 0.006 & 0.077 & 0 & 1 \\
\hline 7 Kids in Household & Household has 7 children $(=1$, yes; $=0$, no $)$ & 0.002 & 0.046 & 0 & 1 \\
\hline 8 Kids in Household & Household has 8 children $(=1$, yes; $=0$, no $)$ & 0.001 & 0.030 & 0 & 1 \\
\hline 9 or more Kids in Household & Household has 9 or more children $(=1$, yes; $=0$, no $)$ & 0.000 & 0.021 & 0 & 1 \\
\hline No. of Kids Age 0 & Number of kids Age 0 in household & 0.000 & 0.000 & 0 & 0 \\
\hline No. of Kids Age 1 & Number of kids Age 1 in household & 0.142 & 0.358 & 0 & 4 \\
\hline No. of Kids Age 2 & Number of kids Age 2 in household & 0.164 & 0.379 & 0 & 5 \\
\hline No. of Kids Age 3 & Number of kids Age 3 in household & 0.163 & 0.376 & 0 & 3 \\
\hline No. of Kids Age 4 & Number of kids Age 4 in household & 0.157 & 0.371 & 0 & 4 \\
\hline No. of Kids Age 5 & Number of kids Age 5 in household & 0.142 & 0.355 & 0 & 3 \\
\hline No. of Kids Age 6 & Number of kids Age 6 in household & 0.131 & 0.343 & 0 & 3 \\
\hline No. of Kids Age 7 & Number of kids Age 7 in household & 0.119 & 0.329 & 0 & 4 \\
\hline No. of Kids Age 8 & Number of kids Age 8 in household & 0.110 & 0.318 & 0 & 3 \\
\hline No. of Kids Age 9 & Number of kids Age 9 in household & 0.101 & 0.307 & 0 & 5 \\
\hline No. of Kids Age 10 & Number of kids Age 10 in household & 0.094 & 0.296 & 0 & 4 \\
\hline No. of Kids Age 11 & Number of kids Age 11 in household & 0.087 & 0.285 & 0 & 3 \\
\hline No. of Kids Age 12 & Number of kids Age 12 in household & 0.081 & 0.276 & 0 & 3 \\
\hline No. of Kids Age 13 & Number of kids Age 13 in household & 0.075 & 0.267 & 0 & 3 \\
\hline
\end{tabular}


Appendix Table 1a, continued

\begin{tabular}{|c|c|c|c|c|c|}
\hline Variable & & Mean & Std Dev & Min & Max \\
\hline No. of Kids Age 14 & Number of kids Age 14 in household & 0.070 & 0.259 & 0 & 3 \\
\hline No. of Kids Age 15 & Number of kids Age 15 in household & 0.065 & 0.250 & 0 & 4 \\
\hline No. of Kids Age 16 & Number of kids Age 16 in household & 0.061 & 0.244 & 0 & 3 \\
\hline No. of Kids Age 17 & Number of kids Age 17 in household & 0.055 & 0.232 & 0 & 3 \\
\hline No. of Kids Age 18 & Number of kids Age 18 in household & 0.048 & 0.217 & 0 & 3 \\
\hline \multicolumn{6}{|c|}{ Demographic Characteristics of Households: } \\
\hline Ave. Adult Age & Mean age of adults in household in given year & 31.374 & 8.507 & 20 & 103 \\
\hline Female Head & Household is headed by female $(=1$, yes; $=0$, no $)$ & 0.933 & 0.249 & 0 & 1 \\
\hline Hispanic & All adults in household are Hispanic & 0.284 & 0.451 & 0 & 1 \\
\hline Black & All adults in household are black & 0.224 & 0.417 & 0 & 1 \\
\hline Asian & All adults in households are Asian & 0.072 & 0.259 & 0 & 1 \\
\hline Other/Mixed Race/Ethnicity & Adults in household are of other and/or mixed races & 0.013 & 0.113 & 0 & 1 \\
\hline \multicolumn{6}{|c|}{ County Welfare Variables and Year of Welfare Entry by Year: } \\
\hline GAIN Proportion & $\begin{array}{l}\text { Average annual proportion AFDC/TANF recipients in county of } \\
\text { residence in GAIN/WTW program }\end{array}$ & 0.362 & 0.262 & 0.036 & 1 \\
\hline Child Care Expend. & $\begin{array}{l}\text { Per capita public expenditures (in 1000s of } \$ 1992 / 93 \text { ) on child care for } \\
\text { low-income population in county of residence in given year }\end{array}$ & 0.023 & 0.039 & 0 & 0.174 \\
\hline Entered AFDC/TANF in 1986 & Household first went on AFDC/TANF in 1986 (= 1, yes; = 0, no) & 0.070 & 0.255 & 0 & 1 \\
\hline Entered AFDC/TANF in 1987 & Household first went on AFDC/TANF in 1987 (= 1, yes; = 0, no) & 0.021 & 0.142 & 0 & 1 \\
\hline Entered AFDC/TANF in 1988 & Household first went on AFDC/TANF in 1988 (= 1, yes; = 0, no) & 0.032 & 0.177 & 0 & 1 \\
\hline Entered AFDC/TANF in 1989 & Household first went on AFDC/TANF in 1989 (= 1, yes; = 0, no) & 0.050 & 0.218 & 0 & 1 \\
\hline Entered AFDC/TANF in 1990 & Household first went on AFDC/TANF in 1990 (= 1, yes; = 0, no) & 0.092 & 0.288 & 0 & 1 \\
\hline Entered AFDC/TANF in 1991 & Household first went on AFDC/TANF in 1991 (= 1, yes; = 0, no) & 0.103 & 0.303 & 0 & 1 \\
\hline Entered AFDC/TANF in 1992 & Household first went on AFDC/TANF in 1992 (= 1, yes; = 0, no) & 0.090 & 0.286 & 0 & 1 \\
\hline Entered AFDC/TANF in 1993 & Household first went on AFDC/TANF in 1993 (= 1, yes; = 0, no) & 0.101 & 0.301 & 0 & 1 \\
\hline Entered AFDC/TANF in 1994 & Household first went on AFDC/TANF in 1994 (= 1, yes; = 0, no) & 0.099 & 0.299 & 0 & 1 \\
\hline Entered AFDC/TANF in 1995 & Household first went on AFDC/TANF in 1995 (= 1, yes; = 0, no) & 0.089 & 0.285 & 0 & 1 \\
\hline Entered AFDC/TANF in 1996 & Household first went on AFDC/TANF in 1996 (= 1, yes; = 0, no) & 0.077 & 0.267 & 0 & 1 \\
\hline Entered AFDC/TANF in 1997 & Household first went on AFDC/TANF in 1997 (= 1, yes; = 0, no) & 0.068 & 0.251 & 0 & 1 \\
\hline Entered AFDC/TANF in 1998 & Household first went on AFDC/TANF in 1998 (= 1, yes; = 0, no) & 0.056 & 0.230 & 0 & 1 \\
\hline Entered AFDC/TANF in 1999 & Household first went on AFDC/TANF in 1999 (= 1, yes; = 0, no) & 0.052 & 0.223 & 0 & 1 \\
\hline
\end{tabular}

(table continues) 


\begin{tabular}{|c|c|c|c|c|c|}
\hline Variable & & Mean & Std Dev & Min & Max \\
\hline \multicolumn{6}{|l|}{ Local Labor Market Characteristics: } \\
\hline Emp-to-Pop & Annual employment-to-population ratio in county of residence & 0.622 & 0.107 & 0.317 & 1.330 \\
\hline Prop. Employ. in Manufacturing & $\begin{array}{l}\text { Proportion of county of residence employment in manufacturing in given } \\
\text { year }\end{array}$ & 0.134 & 0.051 & 0 & 0.305 \\
\hline Prop. Employ. in Services & Proportion of county of residence employment in services in given year & 0.303 & 0.074 & 0 & 0.931 \\
\hline Prop. Employ. in Retail Trade & $\begin{array}{l}\text { Proportion of county of residence employment in retail trade in given } \\
\text { year }\end{array}$ & 0.176 & 0.026 & 0.025 & 0.399 \\
\hline Ave. Earnings, All Sectors & $\begin{array}{l}\text { Average annual earnings per worker in county of residence in 1000s of } \\
\text { 1992/93\$, all sectors }\end{array}$ & 34.417 & 6.690 & 14.278 & 78.381 \\
\hline Ave. Earnings, Manufacturing & $\begin{array}{l}\text { Average annual earnings per worker in county of residence in 1000s of } \\
1992 / 93 \$ \text {, manufacturing sector }\end{array}$ & 41.515 & 9.556 & 0 & 136.017 \\
\hline Ave. Earnings, Services & $\begin{array}{l}\text { Average annual earnings per worker in county of residence in 1000s of } \\
\text { 1992/93\$, service sector }\end{array}$ & 33.313 & 6.979 & 0 & 81.233 \\
\hline Ave. Earnings, Retail Trade & $\begin{array}{l}\text { Average annual earnings per worker in county of residence in 1000s of } \\
\text { 1992/93\$, retail trade sector }\end{array}$ & 19.681 & 2.310 & 8.705 & 33.310 \\
\hline \multicolumn{6}{|c|}{ County of Residence Dummy Variables: } \\
\hline Alameda & Resided in Alameda County at sampling & 0.043 & 0.203 & 0 & 1 \\
\hline Alpine & Resided in Alpine County at sampling & 0.000 & 0.009 & 0 & 1 \\
\hline Amador & Resided in Amador County at sampling & 0.001 & 0.029 & 0 & 1 \\
\hline Butte & Resided in Butte County at sampling & 0.009 & 0.093 & 0 & 1 \\
\hline Calaveras & Resided in Calaveras County at sampling & 0.002 & 0.039 & 0 & 1 \\
\hline Colusa & Resided in Colusa County at sampling & 0.001 & 0.024 & 0 & 1 \\
\hline Contra Costa & Resided in Contra Costa County at sampling & 0.022 & 0.148 & 0 & 1 \\
\hline Del Norte & Resided in Del Norte County at sampling & 0.002 & 0.041 & 0 & 1 \\
\hline El Dorado & Resided in El Dorado County at sampling & 0.004 & 0.062 & 0 & 1 \\
\hline Fresno & Resided in Fresno County at sampling & 0.034 & 0.180 & 0 & 1 \\
\hline Glenn & Resided in Glenn County at sampling & 0.001 & 0.033 & 0 & 1 \\
\hline Humboldt & Resided in Humboldt County at sampling & 0.006 & 0.076 & 0 & 1 \\
\hline Imperial & Resided in Imperial County at sampling & 0.006 & 0.080 & 0 & 1 \\
\hline Inyo & Resided in Inyo County at sampling & 0.001 & 0.027 & 0 & 1 \\
\hline Kern & Resided in Kern County at sampling & 0.029 & 0.167 & 0 & 1 \\
\hline
\end{tabular}


Appendix Table 1a, continued

\begin{tabular}{|c|c|c|c|c|c|}
\hline Variable & & Mean & Std Dev & Min & Max \\
\hline Kings & Resided in Kings County at sampling & 0.006 & 0.079 & 0 & 1 \\
\hline Lake & Resided in Lake County at sampling & 0.004 & 0.060 & 0 & 1 \\
\hline Lassen & Resided in Lassen County at sampling & 0.001 & 0.037 & 0 & 1 \\
\hline Los Angeles & Resided in Los Angeles County at sampling & 0.285 & 0.451 & 0 & 1 \\
\hline Madera & Resided in Madera County at sampling & 0.004 & 0.066 & 0 & 1 \\
\hline Marin & Resided in Marin County at sampling & 0.002 & 0.049 & 0 & 1 \\
\hline Mariposa & Resided in Mariposa County at sampling & 0.001 & 0.027 & 0 & 1 \\
\hline Mendocino & Resided in Mendocino County at sampling & 0.004 & 0.064 & 0 & 1 \\
\hline Merced & Resided in Merced County at sampling & 0.010 & 0.100 & 0 & 1 \\
\hline Modoc & Resided in Modoc County at sampling & 0.001 & 0.024 & 0 & 1 \\
\hline Mono & Resided in Mono County at sampling & 0.000 & 0.014 & 0 & 1 \\
\hline Monterey & Resided in Monterey County at sampling & 0.012 & 0.110 & 0 & 1 \\
\hline Napa & Resided in Napa County at sampling & 0.003 & 0.050 & 0 & 1 \\
\hline Nevada & Resided in Nevada County at sampling & 0.002 & 0.048 & 0 & 1 \\
\hline Orange & Resided in Orange County at sampling & 0.041 & 0.199 & 0 & 1 \\
\hline Placer & Resided in Placer County at sampling & 0.006 & 0.075 & 0 & 1 \\
\hline Plumas & Resided in Plumas County at sampling & 0.001 & 0.029 & 0 & 1 \\
\hline Riverside & Resided in Riverside County at sampling & 0.050 & 0.219 & 0 & 1 \\
\hline Sacramento & Resided in Sacramento County at sampling & 0.052 & 0.222 & 0 & 1 \\
\hline San Benito & Resided in San Benito County at sampling & 0.001 & 0.037 & 0 & 1 \\
\hline San Bernardino & Resided in San Bernardino County at sampling & 0.083 & 0.275 & 0 & 1 \\
\hline San Diego & Resided in San Diego County at sampling & 0.073 & 0.260 & 0 & 1 \\
\hline San Francisco & Resided in San Francisco County at sampling & 0.014 & 0.117 & 0 & 1 \\
\hline San Joaquin & Resided in San Joaquin County at sampling & 0.024 & 0.154 & 0 & 1 \\
\hline San Luis Obispo & Resided in San Luis Obispo County at sampling & 0.005 & 0.072 & 0 & 1 \\
\hline San Mateo & Resided in San Mateo County at sampling & 0.008 & 0.089 & 0 & 1 \\
\hline Santa Barbara & Resided in Santa Barbara County at sampling & 0.008 & 0.088 & 0 & 1 \\
\hline Santa Clara & Resided in Santa Clara County at sampling & 0.033 & 0.179 & 0 & 1 \\
\hline Santa Cruz & Resided in Santa Cruz County at sampling & 0.005 & 0.073 & 0 & 1 \\
\hline Shasta & Resided in Shasta County at sampling & 0.008 & 0.091 & 0 & 1 \\
\hline Sierra & Resided in Sierra County at sampling & 0.000 & 0.012 & 0 & 1 \\
\hline
\end{tabular}


Appendix Table 1a, continued

\begin{tabular}{|c|c|c|c|c|c|}
\hline Variable & & Mean & Std Dev & Min & Max \\
\hline Siskiyou & Resided in Siskiyou County at sampling & 0.003 & 0.054 & 0 & 1 \\
\hline Solano & Resided in Solano County at sampling & 0.013 & 0.113 & 0 & 1 \\
\hline Sonoma & Resided in Sonoma County at sampling & 0.009 & 0.094 & 0 & 1 \\
\hline Stanislaus & Resided in Stanislaus County at sampling & 0.018 & 0.134 & 0 & 1 \\
\hline Sutter & Resided in Sutter County at sampling & 0.003 & 0.058 & 0 & 1 \\
\hline Tehama & Resided in Tehama County at sampling & 0.003 & 0.053 & 0 & 1 \\
\hline Trinity & Resided in Trinity County at sampling & 0.001 & 0.027 & 0 & 1 \\
\hline Tulare & Resided in Tulare County at sampling & 0.016 & 0.126 & 0 & 1 \\
\hline Tuolumne & Resided in Tuolumne County at sampling & 0.002 & 0.047 & 0 & 1 \\
\hline Ventura & Resided in Ventura County at sampling & 0.013 & 0.115 & 0 & 1 \\
\hline Yolo & Resided in Yolo County at sampling & 0.006 & 0.075 & 0 & 1 \\
\hline Yuba & Resided in Yuba County at sampling & 0.004 & 0.064 & 0 & 1 \\
\hline
\end{tabular}


Appendix Table 1b

Weighted Descriptive Statistics for the Longitudinal Analysis Sample $(\mathrm{N}=1,637,855)$

\begin{tabular}{|c|c|c|c|c|c|}
\hline Variable & & Mean & Std Dev & Min & Max \\
\hline \multicolumn{6}{|c|}{ Outcome variables of interest: } \\
\hline Emp & Household employed in year (= 1 if at least 1 adult employed; $=0$ otherwise) & 0.445 & 0.497 & 0 & 1 \\
\hline FiledTax & Household filed tax return in year $(=1$ yes; $=0$ no) & 0.390 & 0.488 & 0 & 1 \\
\hline ClaimEITC & Household filed tax return and claimed EITC in year $(=1$, yes; $=0$, no $)$ & 0.317 & 0.465 & 0 & 1 \\
\hline \multicolumn{6}{|l|}{ Calendar Year Indicators: } \\
\hline Year_1991 & Year $=1991$ & 0.128 & 0.334 & 0 & 1 \\
\hline Year_1992 & Year = 1992 & 0.122 & 0.328 & 0 & 1 \\
\hline Year_1993 & Year = 1993 & 0.122 & 0.327 & 0 & 1 \\
\hline Year_1994 & Year = 1994 & 0.123 & 0.328 & 0 & 1 \\
\hline Year_1995 & Year = 1995 & 0.120 & 0.325 & 0 & 1 \\
\hline Year_1996 & Year = 1996 & 0.113 & 0.316 & 0 & 1 \\
\hline Year_1997 & Year = 1997 & 0.107 & 0.309 & 0 & 1 \\
\hline Year_1998 & Year $=1998$ & 0.081 & 0.272 & 0 & 1 \\
\hline Year_1999 & Year = 1999 & 0.055 & 0.228 & 0 & 1 \\
\hline Year_2000 & Year $=2000$ & 0.029 & 0.169 & 0 & 1 \\
\hline \multicolumn{6}{|c|}{ Treatment and "Testing" Variables: } \\
\hline 2+ Kids in 1991 & Household had 2 or more kids in 1991 & 0.069 & 0.254 & 0 & 1 \\
\hline 2+ Kids in 1992 & Household had 2 or more kids in 1992 & 0.066 & 0.248 & 0 & 1 \\
\hline 2+ Kids in 1993 & Household had 2 or more kids in 1993 & 0.065 & 0.246 & 0 & 1 \\
\hline 2+ Kids in 1994 & Household had 2 or more kids in 1994 & 0.065 & 0.247 & 0 & 1 \\
\hline 2+ Kids in 1995 & Household had 2 or more kids in 1995 & 0.063 & 0.243 & 0 & 1 \\
\hline 2+ Kids in 1996 & Household had 2 or more kids in 1996 & 0.059 & 0.235 & 0 & 1 \\
\hline 2+ Kids in 1997 & Household had 2 or more kids in 1997 & 0.056 & 0.230 & 0 & 1 \\
\hline 2+ Kids in 1998 & Household had 2 or more kids in 1998 & 0.042 & 0.200 & 0 & 1 \\
\hline 2+ Kids in 1999 & Household had 2 or more kids in 1999 & 0.028 & 0.165 & 0 & 1 \\
\hline 2+ Kids in 2000 & Household had 2 or more kids in 2000 & 0.015 & 0.121 & 0 & 1 \\
\hline [2+ Kids-3+ Kids] in 1991 & Household had exactly two children in 1991 & 0.039 & 0.194 & 0 & 1 \\
\hline [2+ Kids-3+ Kids] in 1992 & Household had exactly two children in 1992 & 0.037 & 0.190 & 0 & 1 \\
\hline [2+ Kids-3+ Kids] in 1993 & Household had exactly two children in 1993 & 0.037 & 0.189 & 0 & 1 \\
\hline
\end{tabular}

(table continues) 
Appendix Table 1b, continued

\begin{tabular}{|c|c|c|c|c|c|}
\hline Variable & & Mean & Std Dev & Min & Max \\
\hline [2+ Kids-3+ Kids] in 1994 & Household had exactly two children in 1994 & 0.037 & 0.190 & 0 & 1 \\
\hline [2+ Kids-3+ Kids] in 1995 & Household had exactly two children in 1995 & 0.036 & 0.187 & 0 & 1 \\
\hline [2+ Kids-3+ Kids] in 1996 & Household had exactly two children in 1996 & 0.034 & 0.180 & 0 & 1 \\
\hline [2+ Kids-3+ Kids] in 1997 & Household had exactly two children in 1997 & 0.032 & 0.175 & 0 & 1 \\
\hline [2+ Kids-3+ Kids] in 1998 & Household had exactly two children in 1998 & 0.024 & 0.152 & 0 & 1 \\
\hline [2+ Kids-3+ Kids] in 1999 & Household had exactly two children in 1999 & 0.016 & 0.125 & 0 & 1 \\
\hline [2+ Kids-3+ Kids] in 2000 & Household had exactly two children in 2000 & 0.009 & 0.092 & 0 & 1 \\
\hline \multicolumn{6}{|l|}{ Number and Ages of Children: } \\
\hline 1 Kid in Household & Household has 1 child $(=1$, yes; = 0 , no) & 0.478 & 0.500 & 0 & 1 \\
\hline 2 Kids in Household & Household has 2 children $(=1$, yes; $=0$, no $)$ & 0.301 & 0.459 & 0 & 1 \\
\hline 3 Kids in Household & Household has 3 children $(=1$, yes; $=0$, no $)$ & 0.142 & 0.349 & 0 & 1 \\
\hline 4 Kids in Household & Household has 4 children $(=1$, yes; $=0$, no $)$ & 0.053 & 0.224 & 0 & 1 \\
\hline 5 Kids in Household & Household has 5 children $(=1$, yes; $=0$, no $)$ & 0.017 & 0.131 & 0 & 1 \\
\hline 6 Kids in Household & Household has 6 children $(=1$, yes; $=0$, no $)$ & 0.006 & 0.076 & 0 & 1 \\
\hline 7 Kids in Household & Household has 7 children $(=1$, yes; $=0$, no $)$ & 0.002 & 0.045 & 0 & 1 \\
\hline 8 Kids in Household & Household has 8 children $(=1$, yes; $=0$, no $)$ & 0.001 & 0.030 & 0 & 1 \\
\hline 9 or more Kids in Household & Household has 9 or more children $(=1$, yes; $=0$, no $)$ & 0.000 & 0.019 & 0 & 1 \\
\hline No. of Kids Age 0 & Number of kids age 0 in household & 0.105 & 0.313 & 0 & 5 \\
\hline No. of Kids Age 1 & Number of kids age 1 in household & 0.159 & 0.374 & 0 & 5 \\
\hline No. of Kids Age 2 & Number of kids age 2 in household & 0.165 & 0.379 & 0 & 5 \\
\hline No. of Kids Age 3 & Number of kids age 3 in household & 0.160 & 0.373 & 0 & 4 \\
\hline No. of Kids Age 4 & Number of kids age 4 in household & 0.149 & 0.363 & 0 & 4 \\
\hline No. of Kids Age 5 & Number of kids age 5 in household & 0.137 & 0.349 & 0 & 4 \\
\hline No. of Kids Age 6 & Number of kids age 6 in household & 0.125 & 0.336 & 0 & 4 \\
\hline No. of Kids Age 7 & Number of kids age 7 in household & 0.114 & 0.323 & 0 & 4 \\
\hline No. of Kids Age 8 & Number of kids age 8 in household & 0.105 & 0.312 & 0 & 5 \\
\hline No. of Kids Age 9 & Number of kids age 9 in household & 0.097 & 0.301 & 0 & 5 \\
\hline No. of Kids Age 10 & Number of kids age 10 in household & 0.090 & 0.291 & 0 & 4 \\
\hline No. of Kids Age 11 & Number of kids age 11 in household & 0.084 & 0.281 & 0 & 3 \\
\hline No. of Kids Age 12 & Number of kids age 12 in household & 0.078 & 0.273 & 0 & 3 \\
\hline
\end{tabular}

(table continues) 
Appendix Table 1b, continued

\begin{tabular}{|c|c|c|c|c|c|}
\hline Variable & & Mean & Std Dev & Min & Max \\
\hline No. of Kids Age 13 & Number of kids age 13 in household & 0.073 & 0.264 & 0 & 4 \\
\hline No. of Kids Age 14 & Number of kids age 14 in household & 0.067 & 0.255 & 0 & 4 \\
\hline No. of Kids Age 15 & Number of kids age 15 in household & 0.061 & 0.244 & 0 & 4 \\
\hline No. of Kids Age 16 & Number of kids age 16 in household & 0.047 & 0.214 & 0 & 3 \\
\hline No. of Kids Age 17 & Number of kids age 17 in household & 0.031 & 0.176 & 0 & 3 \\
\hline No. of Kids Age 18 & Number of kids age 18 in household & 0.015 & 0.125 & 0 & 3 \\
\hline \multicolumn{6}{|c|}{ County Welfare Variables and Year of Welfare Entry by Year: } \\
\hline GAIN Proportion & $\begin{array}{l}\text { Average annual proportion AFDC/TANF recipients in county of residence in } \\
\text { GAIN/WTW program }\end{array}$ & 0.309 & 0.225 & 0.036 & 1 \\
\hline Child Care Expend. & $\begin{array}{l}\text { Per capita public expenditures (in 1000s of } \$ 1992 / 93 \text { ) on child care for low- } \\
\text { income population in county of residence in given year }\end{array}$ & 0.017 & 0.028 & 0 & 0.174 \\
\hline Entered AFDC/TANF in 1986 & Household first went on AFDC/TANF in 1986 (= 1, yes; = 0, no) & 0.054 & 0.226 & 0 & 1 \\
\hline Entered AFDC/TANF in 1987 & Household first went on AFDC/TANF in 1987 (= 1, yes; = 0, no) & 0.015 & 0.121 & 0 & 1 \\
\hline Entered AFDC/TANF in 1988 & Household first went on AFDC/TANF in $1988(=1$, yes; $=0$, no $)$ & 0.023 & 0.150 & 0 & 1 \\
\hline Entered AFDC/TANF in 1989 & Household first went on AFDC/TANF in $1989(=1$, yes; $=0$, no $)$ & 0.034 & 0.181 & 0 & 1 \\
\hline Entered AFDC/TANF in 1990 & Household first went on AFDC/TANF in $1990(=1$, yes; $=0$, no $)$ & 0.056 & 0.230 & 0 & 1 \\
\hline Entered AFDC/TANF in 1991 & Household first went on AFDC/TANF in $1991(=1$, yes; $=0$, no $)$ & 0.090 & 0.286 & 0 & 1 \\
\hline Entered AFDC/TANF in 1992 & Household first went on AFDC/TANF in $1992(=1$, yes; = 0, no) & 0.096 & 0.295 & 0 & 1 \\
\hline Entered AFDC/TANF in 1993 & Household first went on AFDC/TANF in $1993(=1$, yes; = 0, no) & 0.121 & 0.326 & 0 & 1 \\
\hline Entered AFDC/TANF in 1994 & Household first went on AFDC/TANF in 1994 (= 1, yes; = 0, no) & 0.117 & 0.322 & 0 & 1 \\
\hline Entered AFDC/TANF in 1995 & Household first went on AFDC/TANF in $1995(=1$, yes; $=0$, no $)$ & 0.105 & 0.307 & 0 & 1 \\
\hline Entered AFDC/TANF in 1996 & Household first went on AFDC/TANF in $1996(=1$, yes; = 0, no) & 0.090 & 0.286 & 0 & 1 \\
\hline Entered AFDC/TANF in 1997 & Household first went on AFDC/TANF in 1997 (= 1, yes; = 0, no) & 0.078 & 0.268 & 0 & 1 \\
\hline Entered AFDC/TANF in 1998 & Household first went on AFDC/TANF in $1998(=1$, yes; $=0$, no $)$ & 0.063 & 0.244 & 0 & 1 \\
\hline Entered AFDC/TANF in 1999 & Household first went on AFDC/TANF in $1999(=1$, yes; = 0, no) & 0.058 & 0.233 & 0 & 1 \\
\hline \multicolumn{6}{|c|}{ Local Labor Market Characteristics: } \\
\hline Emp-to-Pop & Annual employment-to-population ratio in county of residence & 0.617 & 0.106 & 0.317 & 1.330 \\
\hline Prop. Employ. Manuf. & $\begin{array}{l}\text { Proportion of county of residence employment in manufacturing in given } \\
\text { year }\end{array}$ & 0.135 & 0.051 & 0 & 0.305 \\
\hline Prop. Employ. Services & Proportion of county of residence employment in services in given year & 0.292 & 0.071 & 0 & 0.931 \\
\hline
\end{tabular}

(table continues) 


\section{Appendix Table 1b, continued}

\begin{tabular}{|c|c|c|c|c|c|}
\hline Variable & & Mean & Std Dev & Min & Max \\
\hline Prop. Employ. Retail Trade & Proportion of county of residence employment in retail trade in given year & 0.176 & 0.026 & 0.025 & 0.399 \\
\hline Ave. Earnings, All Sectors & $\begin{array}{l}\text { Average annual earnings per worker in county of residence in 1000s of } \\
\text { 1992/93\$, all sectors }\end{array}$ & 34.109 & 6.297 & 14.278 & 78.381 \\
\hline Ave. Earnings, Manuf. & $\begin{array}{l}\text { Average annual earnings per worker in county of residence in 1000s of } \\
1992 / 93 \$ \text {, manufacturing sector }\end{array}$ & 40.993 & 8.416 & 0 & 136.017 \\
\hline Ave. Earnings, Services & $\begin{array}{l}\text { Average annual earnings per worker in county of residence in 1000s of } \\
1992 / 93 \$ \text {, service sector }\end{array}$ & 33.000 & 6.788 & 0 & 81.233 \\
\hline Ave. Earnings, Retail Trade & $\begin{array}{l}\text { Average annual earnings per worker in county of residence in 1000s of } \\
1992 / 93 \$ \text {, retail trade sector }\end{array}$ & 19.521 & 2.225 & 8.705 & 33.310 \\
\hline Ave. Adult Age & Mean age of adults in household in given year & 30.687 & 8.430 & 19 & 103 \\
\hline Female Head & Household is headed by female $(=1$, yes; $=0$, no $)$ & 0.928 & 0.259 & 0 & 1 \\
\hline Hispanic & All adults in household are Hispanic & 0.296 & 0.456 & 0 & 1 \\
\hline Black & All adults in household are black & 0.220 & 0.414 & 0 & 1 \\
\hline Asian & All adults in households are Asian & 0.072 & 0.259 & 0 & 1 \\
\hline Other/Mixed Race/Ethnicity & Adults in household are of other and/or mixed races & 0.012 & 0.111 & 0 & 1 \\
\hline \multicolumn{6}{|c|}{ County of Residence Dummy Variables: } \\
\hline Alameda & Resided in Alameda County at sampling & 0.043 & 0.202 & 0 & 1 \\
\hline Alpine & Resided in Alpine County at sampling & 0.000 & 0.009 & 0 & 1 \\
\hline Amador & Resided in Amador County at sampling & 0.001 & 0.029 & 0 & 1 \\
\hline Butte & Resided in Butte County at sampling & 0.009 & 0.094 & 0 & 1 \\
\hline Calaveras & Resided in Calaveras County at sampling & 0.002 & 0.039 & 0 & 1 \\
\hline Colusa & Resided in Colusa County at sampling & 0.001 & 0.024 & 0 & 1 \\
\hline Contra Costa & Resided in Contra Costa County at sampling & 0.022 & 0.147 & 0 & 1 \\
\hline Del Norte & Resided in Del Norte County at sampling & 0.002 & 0.041 & 0 & 1 \\
\hline El Dorado & Resided in El Dorado County at sampling & 0.004 & 0.061 & 0 & 1 \\
\hline Fresno & Resided in Fresno County at sampling & 0.033 & 0.179 & 0 & 1 \\
\hline Glenn & Resided in Glenn County at sampling & 0.001 & 0.032 & 0 & 1 \\
\hline Humboldt & Resided in Humboldt County at sampling & 0.006 & 0.075 & 0 & 1 \\
\hline Imperial & Resided in Imperial County at sampling & 0.007 & 0.081 & 0 & 1 \\
\hline Inyo & Resided in Inyo County at sampling & 0.001 & 0.027 & 0 & 1 \\
\hline Kern & Resided in Kern County at sampling & 0.029 & 0.167 & 0 & 1 \\
\hline
\end{tabular}




\section{Appendix Table 1b, continued}

\begin{tabular}{|c|c|c|c|c|c|}
\hline Variable & & Mean & Std Dev & Min & Max \\
\hline Kings & Resided in Kings County at sampling & 0.006 & 0.079 & 0 & 1 \\
\hline Lake & Resided in Lake County at sampling & 0.004 & 0.061 & 0 & 1 \\
\hline Lassen & Resided in Lassen County at sampling & 0.001 & 0.038 & 0 & 1 \\
\hline Los Angeles & Resided in Los Angeles County at sampling & 0.288 & 0.453 & 0 & 1 \\
\hline Madera & Resided in Madera County at sampling & 0.004 & 0.067 & 0 & 1 \\
\hline Marin & Resided in Marin County at sampling & 0.002 & 0.049 & 0 & 1 \\
\hline Mariposa & Resided in Mariposa County at sampling & 0.001 & 0.027 & 0 & 1 \\
\hline Mendocino & Resided in Mendocino County at sampling & 0.004 & 0.064 & 0 & 1 \\
\hline Merced & Resided in Merced County at sampling & 0.010 & 0.101 & 0 & 1 \\
\hline Modoc & Resided in Modoc County at sampling & 0.001 & 0.024 & 0 & 1 \\
\hline Mono & Resided in Mono County at sampling & 0.000 & 0.014 & 0 & 1 \\
\hline Monterey & Resided in Monterey County at sampling & 0.013 & 0.112 & 0 & 1 \\
\hline Napa & Resided in Napa County at sampling & 0.002 & 0.049 & 0 & 1 \\
\hline Nevada & Resided in Nevada County at sampling & 0.002 & 0.048 & 0 & 1 \\
\hline Orange & Resided in Orange County at sampling & 0.042 & 0.200 & 0 & 1 \\
\hline Placer & Resided in Placer County at sampling & 0.006 & 0.075 & 0 & 1 \\
\hline Plumas & Resided in Plumas County at sampling & 0.001 & 0.029 & 0 & 1 \\
\hline Riverside & Resided in Riverside County at sampling & 0.051 & 0.220 & 0 & 1 \\
\hline Sacramento & Resided in Sacramento County at sampling & 0.052 & 0.222 & 0 & 1 \\
\hline San Benito & Resided in San Benito County at sampling & 0.001 & 0.037 & 0 & 1 \\
\hline San Bernardino & Resided in San Bernardino County at sampling & 0.083 & 0.276 & 0 & 1 \\
\hline San Diego & Resided in San Diego County at sampling & 0.072 & 0.259 & 0 & 1 \\
\hline San Francisco & Resided in San Francisco County at sampling & 0.013 & 0.114 & 0 & 1 \\
\hline San Joaquin & Resided in San Joaquin County at sampling & 0.024 & 0.153 & 0 & 1 \\
\hline San Luis Obispo & Resided in San Luis Obispo County at sampling & 0.005 & 0.073 & 0 & 1 \\
\hline San Mateo & Resided in San Mateo County at sampling & 0.008 & 0.088 & 0 & 1 \\
\hline Santa Barbara & Resided in Santa Barbara County at sampling & 0.008 & 0.088 & 0 & 1 \\
\hline Santa Clara & Resided in Santa Clara County at sampling & 0.032 & 0.175 & 0 & 1 \\
\hline Santa Cruz & Resided in Santa Cruz County at sampling & 0.005 & 0.073 & 0 & 1 \\
\hline Shasta & Resided in Shasta County at sampling & 0.008 & 0.091 & 0 & 1 \\
\hline Sierra & Resided in Sierra County at sampling & 0.000 & 0.011 & 0 & 1 \\
\hline
\end{tabular}


Appendix Table 1b, continued

\begin{tabular}{|c|c|c|c|c|c|}
\hline Variable & & Mean & Std Dev & Min & Max \\
\hline Siskiyou & Resided in Siskiyou County at sampling & 0.003 & 0.054 & 0 & 1 \\
\hline Solano & Resided in Solano County at sampling & 0.013 & 0.113 & 0 & 1 \\
\hline Sonoma & Resided in Sonoma County at sampling & 0.009 & 0.094 & 0 & 1 \\
\hline Stanislaus & Resided in Stanislaus County at sampling & 0.018 & 0.134 & 0 & 1 \\
\hline Sutter & Resided in Sutter County at sampling & 0.003 & 0.057 & 0 & 1 \\
\hline Tehama & Resided in Tehama County at sampling & 0.003 & 0.053 & 0 & 1 \\
\hline Trinity & Resided in Trinity County at sampling & 0.001 & 0.027 & 0 & 1 \\
\hline Tulare & Resided in Tulare County at sampling & 0.016 & 0.125 & 0 & 1 \\
\hline Tuolumne & Resided in Tuolumne County at sampling & 0.002 & 0.047 & 0 & 1 \\
\hline Ventura & Resided in Ventura County at sampling & 0.013 & 0.114 & 0 & 1 \\
\hline Yolo & Resided in Yolo County at sampling & 0.006 & 0.074 & 0 & 1 \\
\hline Yuba & Resided in Yuba County at sampling & 0.004 & 0.064 & 0 & 1 \\
\hline
\end{tabular}




\section{References}

Bartik, Timothy J., and Randall W. Eberts. 1999. "Examining the Effects of Industry Trends and Structure on Welfare Caseloads.” W.E. Upjohn Institute for Employment Research, Kalamazoo, MI, February.

Becerra, Rosina M., Vivian Lew, Michael N. Mitchell, and Hiromi Ono. 1998. Final Report: California Work Pays Demonstration Project, Report of the First Forty-Two Months. School of Public Policy and Social Research, University of California, Los Angeles, October.

Cancian, Maria, and Arik Levinson. 2003. "Labor Supply and Participation Effect of the Earned Income Tax Credit: Evidence from the National Survey of America's Families and Wisconsin's Supplemental Benefit for Families with Three Children.” Mimeo, University of WisconsinMadison and Georgetown University, http://www.georgetown.edu/faculty/aml6/pdfs\&zips/Cancian-Levinson.pdf.

Dickert, Stacy, Scott Houser, and John Karl Scholz. 1995. "The Earned Income Tax Credit and Transfer Programs: A Study of Labor Market and Program Participation.” In Tax Policy and the Economy, ed. James M. Poterba. Cambridge, MA: National Bureau of Economic Research and the MIT Press.

Eissa, Nada, and Hilary Williamson Hoynes. 2004. "Taxes and the Labor Market Participation of Married Couples: The Earned Income Tax Credit.” Journal of Public Economics 88: 1931-1958.

Eissa, Nada, and Jeffrey B. Liebman. 1996. "Labor Supply Response to the Earned Income Tax Credit." Quarterly Journal of Economics May: 605-637.

Ellwood, David T. 2000. “The Impact of the Earned Income Tax Credit and Social Policy Reforms on Work, Marriage, and Living Arrangements.” National Tax Journal 53 (4, Part 2, December): 1063-1105.

Grogger, Jeffrey. 2003. “The Effects of Time Limits, the EITC, and Other Policy Changes on Welfare Use, Work, and Income among Female-Headed Families.” Review of Economics and Statistics 85(2): 394-408.

Heckman, James J. 1996. “Comment.” In Empirical Foundations of Household Taxation, ed. Martin Feldstein and James Poterba. Chicago: NBER and University of Chicago Press.

Heckman, James J., and Richard Robb. 1985. "Alternative Methods for Evaluating the Impact of Interventions.” In Longitudinal Analysis in Labor Market Data, ed. by James J. Heckman and Burton Singer. New York: Cambridge University Press, Econometric Society Monographs Series.

Hotz, V. Joseph, and Robert A. Miller. 1988. “An Empirical Model of Life Cycle Fertility and Female Labor Supply.” Econometrica 56(1): 91-118.

Hotz, V. Joseph, Charles H. Mullin, and John Karl Scholz. 2002a. "The Effects of Welfare Reform on Employment and Income: Evidence from California.” Mimeo, http://www.ssc.wisc.edu/ scholz/Research/CWPDP_paper_version6.pdf. 
Hotz, V. Joseph, Charles H. Mullin, and John Karl Scholz. 2002b. "Welfare, Employment and Income: Evidence on the Effects of Benefit Reductions in California." American Economic Review, Papers and Proceedings, May: 380-384.

Hotz, V. Joseph, and John Karl Scholz. 2002. "Measuring Employment and Income Outcomes for LowIncome Populations with Administrative and Survey Data.” In Studies of Welfare Populations: Data Collection and Research Issues. Washington, DC: National Academy Press.

Hotz, V. Joseph, and John Karl Scholz. 2003. “The Earned Income Tax Credit.” In Means-Tested Transfer Programs in the United States, ed. Robert Moffitt. Chicago: University of Chicago Press and NBER.

Hotz, V. Joseph, Guido Imbens, and Jacob Klerman. 2005. "Evaluating the Differential Effects of Alternative Welfare-to-Work Training Components: A Re-Analysis of the California GAIN Program.” Unpublished manuscript, UCLA, http://www.econ.ucla.edu/hotz/working_papers/gain2.pdf.

Keane, Michael, and Robert Moffitt. 1998. "A Structural Model of Multiple Welfare Program Participation and Labor Supply.” International Economic Review 39 (3): 553-589.

Marrufo, Grecia, Margaret O’Brien-Strain, and Helen Oliver. 2003. “Child Care Price Dynamics in California.” Mimeo, Public Policy Institute of California, http://www.ppic.org/content/pubs/R_1203GMR.pdf.

Meyer, Bruce D., and Dan T. Rosenbaum. 2000. "Making Single Mothers Work: Recent Tax and Welfare Policy and Its Effects.” National Tax Journal 53 (4, Part 2, December): 1027-1061.

Meyer, Bruce D., and Dan T. Rosenbaum. 2001. "Welfare, the Earned Income Tax Credit, and the Labor Supply of Single Mothers.” Quarterly Journal of Economics 116 (3, August): 1063-1114.

Meyers, Marcia K., Bonnie Glaser, and Karin MacDonald. 1998. "On the Front Lines of Welfare Delivery: Are Workers Implementing Policy Reforms?” Journal of Policy Analysis and Management 17(1): 1-22.

Moffitt, Robert A., and Mark O. Wilhelm. 2000. "Taxation and the Labor Supply Decisions of the Affluent.” In Does Atlas Shrug? The Economic Consequences of Taxing the Rich, ed. Joel Slemrod. Cambridge, MA: Harvard University Press and Russell Sage Foundation.

Riccio, James, Barbara Goldman, Gayle Hamilton, Karin Martinson, and Alan Orenstein. 1989. Gain: Early Implementation Experiences and Lessons, Manpower Demonstration Research Corporation. April. 